\title{
A Joint Venture Internacional e sua Aprovação consoante a Lei Antitruste Brasileira
}

\author{
Thiago V. Flores
}

I) Introdução - 1 ; II) As Joint Ventures Internacionais - 3; A) Origem e conceituação do mecanismo - 3; B) Os elementos caracterizadores das Joint Ventures no caso concreto - 6; C) A taxionomia dessa espécie particular de relação jurídica - 7; D) Vantagens e motivações que induzem à utilização das joint ventures internacionais - 10; III) O procedimento de notificação e aprovação das Joint Ventures Internacionais contido na Lei Antitruste Braşileira - 12; A) Os prazos do procedimento de notificação - 15; B) O CADE: natureza e discricionariedade - 16; C) Submissão voluntária da joint venture internacional ao controle prévio do $\mathrm{CADE}$ - 20; D) Notificação obrigatória da joint venture internacional -23 ; E) Aprovação das joint ventures internacionais que prejudicam a concorrência ou resultam em domínio de mercado relevante $-26 ; \mathrm{F}$ ) O caminho adotado pelo CADE na tomada de suas decisóes e a definição de mercado relevante - 29; G) Revisão e efeitos jurídicos das decisões tomadas pelo CADE - 31; IV) A defesa dos consumidores e a Lei n. 8.884/94 - 32; V) Conclusão - 36.

\section{I - Introdução}

O atual desenvolvimento do comércio internacional demanda aos agentes econômicos, cada vez mais, a busca por maiores recursos técnicos, contribuiçóes financeiras maiores, equipamentos mais sofisticados, que, normalmente, uma empresa não está em capacidade de obtê-los ou provê-los por si mesma, razão pela qual necessita da participação de outra entidade que colabore em determinada atividade econômica específica através do aporte de recursos financeiros, do conhecimento tecnológico, de equipamentos ou pesquisa, de maneira tal que, conjuntamente, podem levar a cabo o desenvolvimento dessa atividade e, assim, suportar a concorrência acirrada do mercado internacional ${ }^{1}$.

10. As questôes levantadas no decorrer to presente trabalho e nas conclusões 6, 
Nesse contexto de necessária preparação tanto econômico-financeira, como tecnológica e administrativa, surge uma nova forma ou método de cooperação entre empresas, de um mesmo país ou de países diferentes, com vista à realização de um projeto específico, uma aventura comum, independente de qual seja a forma jurídica adotada $^{2}$.

Trata-se da joint venture ${ }^{3}$, expressão sem equivalência em nosso idioma, consistente, portanto, em modelo estratégico de parceria empresarial que tem sido amplamente utilizado no cenário econômico internacional não só como pressuposto de sobrevivência e ampliação de mercados frente à evolução do comércio internacional, mas também como incremento para o desenvolvimento tecnológico da empresa participante, bem como do país de sua atuação $0^{4}$.

A joint venture internacional ${ }^{5}$, cuja formação no âmbito da legislação antitruste brasileira é o objeto do presente trabalho, não só o é, como será um dos instrumentos contratuais mais utilizados no novo mercado global que surge e se apresenta como característica do século XXI, mormente em função de sua flexibilidade e capacidade de adaptação às mais diversas atividades econômicas ${ }^{6}$. Vários são os benefícios alcançados pelas empresas que se utilizam deste método de cooperação empresarial, dentre os quais destacam-se a divisão dos riscos inerentes ao negócio no qual estão engajadas, a assimilação da mais moderna tecnologia e técnicas administrativas, a inserção em novos mercados, e principalmente a preparação e fortalecimento para enfrentar o mercado altamente competitivo?.

No entanto, em que pese as evidentes vantagens alcançadas com a opção pela forma associativa in focu, tanto para as empresas como para o país hospedeiro da joint venture, no momento de sua formação devem ser observadas as implicações desta

7, 8 e 9, referentes ao procedimento de notificação estabelecido no artigo 54 da Lei n. $8.884 / 94$, tornaram-se prioridades no campo da política concorrencial e reforma regulatória, de tal forma que provavelmente serão objeto de consideração na criação de nova legislação em futuro próximo.

11. A Lei Antitruste brasileira tem como objetivo, dentre outros, disponibilizar à Administração Pública um instrumento com o qual possa orientar ou manipular as decisões dos grandes grupos de empresas que controlam a atividade econômica, para fins de se fazer implementar o desenvolvimento possível e almejado da política econômica. Tem como escopo, ademais, a proteção da livre concorrência e a defesa dos consumidores. A exemplo da orientação européia, resta estreme de dúvidas, pela análise do texto constitucional, que a concorrência é tida, no Brasil, como instrumento para alcance de um bem maior consistente no "assegurar a todos existência digna conforme os ditames da justiça social." (artigo 170 da Constituição Federal)

' HART, José Léon Barandiarán. El Contrato de Joint Venture. Contratos y Empresa. Lima-Peru: Revista Peruana de Derecho de la Empresa, 1988. p. 31. 


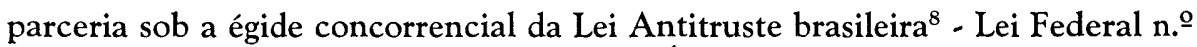
8.884/94, publicada no D.O.U. de 13.06.94. É extremamente necessário fiscalizar a constituição ou formação das joint ventures internacionais no país, como forma de reprimir ou evitar que, por meio da concentração de empresas, se atente contra a ordem econômica nacional. Cabe ao Conselho Administrativo de Defesa Econômica (CADE) exercer o controle prévio sobre as joint ventures internacionais, no momento de suas formações, através da análise dos seus efeitos econômicos e de mercado.

Com efeito, a Lei n.o 8.884/94 dispõe sobre a prevenção e a repressão às infraçóes contra a ordem econômica, estando fulcrada nos mandamentos constitucionais contidos nos artigos $173, \S 4^{\circ}$, e 174 , caput, da Constituição Federal de $1988^{\circ}$, que, sinteticamente, estabelecem o exercício da função fiscalizadora do Estado com vista à repressão do abuso do poder econômico que vise à dominação dos mercados, à eliminação da concorrência e ao aumento arbitrário dos lucros. Ademais, procura-se, por meio da referida função fiscalizadora, preservar os interesses maiores dos consumidores, cuja proteção é consagrada constitucionalmente ${ }^{10} \mathrm{e}$ objetivada pela lei de proteção à concorrência.

A Lei Antitruste brasileira foi criada na chamada era moderna de política concorrencial no Brasil, momento em que o processo de privatização estava por desabrochar. Ainda que relativamente nova, a lei em questão possui um número bastante considerável de problemas conceituais e substantivos, de forma que provavelmente será objeto de alterações por meio de um novo texto sob revisão e análise do Congresso Nacional.

A importância do tema está justamente em ressaltar a necessidade de aplicação prudente das leis que visam coibir a concorrência desleal, através da análise cautelosa e discernida por parte de quem as aplicam, com vistas a evitar resultados indesejáveis à economia nacional e aos consumidores. Ademais, presta-se a alertar aos agentes econômicos e respectivos advogados sobre a necessidade de submeter-se a maioria das joint ventures ${ }^{11}$ (artigo 54 da Lei n. $98.884 / 94$ ), independentemente de sua magnitude, ao crivo prévio da autoridade antitruste, sob pena de se incorrer em multa ou processo administrativo (artigo $54, \S 5^{\circ}$, da Lei n.o $8.884 / 94$ ) que lhes sejam prejudiciais e que ponham em risco toda a negociação já efetivada com o parceiro estrangeiro ${ }^{12}$. Por fim,

2 BASSO, Maristela. Joint Ventures - Manual prático das associações empresariais. Porto Alegre: Livraria do Advogado, 1998. p. 41-42.

${ }^{3}$ Sobre as joint ventures, indica-se a leitura das seguintes obras: LE PERA, Segio. Joint Venture y sociedad: acuerdos de coparticipación empresaria.Buenos Aires: Editorial Astrea, 1984; CORNO, Fabio. Joint Venture. Versione italiana de Kathryn Rudie Harrigan. Padova: CEDAM, 1988; ASTOLFI, Andrea. El contrato internacional de joint venture. Cuadernos de la Revista del Derecho Internacional y de las Obligaciones, Buenos Aires, 1983; BAPTISTA, Luiz Olavo. A joint venture: uma perspectiva comparatista. Revista de Direito Mercantil, São Paulo, n. 42, abr./jun. 1983; BASSO, Maristela. Joint Ventures: manual prático das Associações Empresariais. Porto Alegre: Livraria do Advogado, 1998; GAMBARO, Carlos Maria. O contrato internacional de joint venture.Revista de Informação Legislativa, Brasília, n.146, 2000; SIERRALTA RIOS, Aníbal. Joint Venture Internacional. Buenos Aires. 1996. 
o assunto adquire maior relevância quando levado em consideração o impacto econômico proporcionado pelo aumento do investimento direto estrangeiro verificado nos anos noventa, por intermédio das joint ventures internacionais.

Como forma de atingir os objetivos anteriormente referidos, o presente trabalho será dividido em duas partes: a primeira, na qual se fará uma análise superficial das origens e conceituação dos joint ventures, bem assim suas características, taxionomia e vantagens; e a segunda, aonde se criticará e fará uma análise exegética dos dispositivos da legislação antitruste vigente, bem como se verificará os passos tomados pelos agentes econômicos e conselheiros do CADE no processo de formação e autorização das joint ventures internacionais.

\section{II - As Joint Ventures Internacionais}

\section{A - Origem e conceituação do mecanismo}

Muito se tem tentado estabelecer um conceito preciso $^{13}$, definitivo ou absoluto do que seja uma joint venture internacional, mormente tendo em vista à margem de imprecisão inerente às peculiaridades das relações econômicas internacionais ${ }^{14}$.

Em realidade, juridicamente, inexiste definição legal exata que delimite a expressão joint venture. Nascida para resolver questōes de ordem prática, a joint venture não possui um conceito definitivo e absoluto ${ }^{15}$. Ao contrário, seu conceito é amplamente genérico e ingratamente lato e impreciso ${ }^{16}$. Doutrinariamente ou jurisprudencialmente predomina a imprecisão terminológica, o que torna esse instituto um conceito 'fluído'17. A expressão é utilizada para designar qualquer tipo de estratégia empresarial, desde simples contrato de colaboração até união total de sociedades em uma só empresa.

Em que pese não se possa negar a problemática da conceituação deste instituto que, diga-se de passagem, é estranho ao ordenamento jurídico da grande maioria dos países, "o melhor é não correr o risco de congelar essa figura em um ou outro instituto conhecido de direito interno (nacional), e considerar que as joint ventures são

\footnotetext{
${ }^{4}$ LUPATELLI JR., Alfredo; e MARTINS, Eliane Maria Octaviano. Joint Venture - Aspectos legais e estratégicos. Revista de Derecho del Mercosur. Buenos Aires - Argentina: La Ley, v. 3, n. 2, 1999. p. 194.

${ }^{5}$ As obras indicadas na nota n. ${ }^{\circ} 3$ dedicam grande parte de seus textos ao estudo das joint ventures internacionais.

6 GAMBARO, Carlos Maria. O Contrato Internacional de Joint Venture. Revista de Informação Legis/ativa. Brasilia: Subsecretaria de Edições Técnicas do Senado Federal, n. 146, 2000. p. 62.

${ }^{7}$ LE PERA, Sergio. Joint Venture y Sociedad. Buenos Aires - Argentina: Editorial Astrea, 1984. p. 88.

${ }^{8}$ LUPATELLI JR, Alfredo; e MARTINS, Eliane Maria Octaviano. Defesa da concorrência e joint ventures no Brasil. Revista de Derecho del Mercosur. Buenos Aires - Argentina: La Ley, v. 3, $n$. 4, 1999. p.180.
} 
mecanismos de cooperação entre empresas, que não tem forma específica, tendo em vista sua origem e seu caráter contratual... ${ }^{18 "}$

Em linhas gerais, sobre sua concepção é lícito afirmar que a joint venture "mas que una integración empresarial debe ser visto como un acto de colaboración, podría hablarse de una "affectio cooperationis", como lo hace la professora canadiense Nicole Lacasse, pues se trata de la realización de una obra común. ${ }^{19 "} \mathrm{Ou}$, consoante entendimento de Irineu Strenger ${ }^{20}$, encontra-se na joint venture uma fórmula contratual que consente na instauração de relação de colaboração ocasional sem determinação obrigatória de um esquema societário. Essa última característica apontada pelo conceituado autor diz com a existência de duas espécies formais de joint ventures: uma, com constituição de uma empresa independente (joint venture societária); e outra, apenas contratual (joint venture contratual), daí porque "sem determinação obrigatória de um esquema societário". Sobre a taxionomia das joint ventures discorrer-se-á no decorrer do presente estudo.

Juridicamente, a primeira aparição da expressão joint venture ocorreu no início do século XIX, mais precisamente em dois julgados norte-americanos datados de $1808^{21}$.

No entanto, é compartilhada pela doutrina a opinião de que a "joint venture", tal como hoje é concebida, é originária dos Estados Unidos, tendo surgido na segunda metade do século XIX ${ }^{22}$, onde se desenvolveu e espalhou-se pelo mundo ocidental, impulsionada pela crescente expansão dos interesses norte-americanos na esfera internacional ${ }^{23}$. Para Luiz Olavo Baptista e Aníbal Sierralta Rios ${ }^{24}$ a joint venture originouse através de "uma mescla da criação civilista e do interesse prático e consuetudinário da common law."

Consoante os ensinamentos de Sergio Le Pera 25 "el joint venture, como específica noción jurídica, es justamente una creación de la jurisprudencia moderna destinada a

\footnotetext{
${ }^{9}$ FONSECA, João Bosco Leopoldino da. Lei de proteção da concorrência - Comentários à Lei Antitruste. Rio de Janeiro: Forense, 1995. p. 52.

${ }_{10}$ Artigo 170, inciso V, da Constituição Federal de 1988.

11 Em relação aos atos cuja eficácia está sujeita à aprovação pelo CADE, Fábio Ulhoa Coelho sustenta que os agentes econômicos ao realizá-lo devem analisar concretamente os efeitos jurídicos potenciais e efetivos da transação. COELHO, Fábio Ulhoa. Direito Antitruste Brasileiro - Comentários à Lei n. 8.884/94. Sāo Paulo: Saraiva, 1995. p. 125.

${ }^{12}$ Cf. POPP, Carlyle; e ABDALA, Edson Vieira. Comentários à nova Lei Antitruste. Curitiba: Juruá Editora, 1994. p. 129.

${ }^{13}$ ALFREDO LUPATELLI JR. e ELIANE MARTINS assinalam que, não obstante a imprecisão terminológica da joint venture, a tipologia aberta da forma em que se encontra atualmente"oferece um maior grau de liberdade à evoluçāo dos negócios, acompanhando dessa forma o dinamismo das relações econômicas". Joint Venture: aspectos legais estratégicos. Revista de Derecho del Mercosur, Buenos Aires, v.3, n.2, 1999. p. 196.

${ }^{14}$ BASSO, 1998. p. 45.

${ }^{15} \mathrm{ASTOLFI}$, Andrea. El contrato internacional de joint venture. Cuadernos de la Revista del Derecho Internacional y de las Obligaciones, Buenos Aires, 1983. p. $2 .{ }^{16} \mathrm{Nesse}$ sentido manifesta-se LOBO, C. A. da Silveira. As Joint Ventures. Revista de Direito Renovar. Rio de Janeiro, v.1, 1995. p. 80.
} 
eludir la prohibición según la cual una sociedad por acciones (corporation) no podía formar parte de una sociedad que no fuese por acciones (partnership) ${ }^{26}$.

Mais recentemente, dentro da Comunidade Européia operou-se o desenvolvimento de uma espécie de joint venture, calcada no Groupement d'Interêt Economique ${ }^{27}$, previsto na lei francesa n. 921 , de 23.09.1967. Foi, inclusive, preparado pela Comunidade Européia um projeto de lei uniforme, já adotado por alguns países, com o objetivo de disciplinar os "Agrupamentos de Interesses Econômicos Europeus", cuja a finalidade precípua é facilitar e encorajar a associação e cooperação empresarial transnacional, intrabloco ${ }^{28}$.

De outro lado, não podemos, infelizmente, dizer que o mesmo ocorre no Mercosul. Estamos distante da realidade européia, na qual as instituições supranacionais determinam os caminhos do bloco, estabelecendo diretrizes e fiscalizando comportamentos $^{29}$. Não obstante isso, é válido afirmar que começou a surgir no Mercosul o entendimento de que o isolacionismo não é benéfico, principalmente em função da internacionalização comercial e interdependência econômica crescente entre os países da sociedade internacional. O interesse econômico crescente produziu, e ainda produz, nos futuros parceiros, uma atração pelo investimento em locais com vantagens de ordem econômica e culturais.

A mola propulsora das alianças empresarias no Mercosul consiste nos acordos setoriais. Esses, por sua vez, foram regulamentados pela Decisão n. 03 do Conselho do Mercado Comum ${ }^{30}$ publicada em 17/12/91, baseada no artigo 5, letra "d", do Tratado de Assunção, sobre Termos de Referência para Acordos Setoriais. O artigo $1^{\circ}$ da decisão supracitada, aponta como sua finalidade fundamental o favorecimento da integração entre os setores, promoção da racionalização e a complementação entre mercados e associações, com o objetivo primordial de propiciar a competição de modo eficiente

\footnotetext{
${ }^{17}$ LUPATELLI JÚNIOR., MARTINS, 1999. p. 195.

${ }^{18}$ BASSO, 1998. p. 45.

${ }^{19 H A R T}$, 1988. p. 37. Da mesma opiniāo comunga Maristela Basso para quem a "joint venture corresponde a uma forma ou método de cooperação entre empresas independentes, denominadas em outros países de sociedade de sociedades, filial comum, associação de empresas, etc.". BASSO, 1998. p. 41.

${ }^{20}$ STRENGER, Irineu. Contratos Internacionais do Comércio. 3.ed. Sāo Paulo: Ltr, 1998. p. 399.

21 Jurisprudência norte-americana: "Hourquebi v. Girard", 2 Whas., c.c. 212 (C.C. Pa); e "Lyles V. Styles", 2 Whas., c.c. 224 (C.C. pa. 1808).

22LOBO, 1995. p. 78; e GAMBARO, 2000. p. 64.

${ }^{23}$ Para maior aprofundamento sobre as origens e evolução das joint ventures nos Estados Unidos e Reino Unido, vide CORNO, Fabio. Joint Venture. Versione italiana de Kathryn Rudie Harrigan. Padova: CEDAM, 1988. p. 9-11.

${ }^{24}$ RIOS, Aníbal Sierralta; e BAPTISTA, Luiz Olavo. Aspectos jurídicos del comercio internacional. Lima: Fondo Editorial, 1992. p. 185.

${ }^{25}$ LE PERA, 1984. p. 25.

${ }^{26}$ No mesmo sentido discorre Maristela Basso que, referindo-se à Joint Venture afirma que "surgiu nos Estados Unidos para ludibriar a proibição de que uma sociedade anônima fosse sócia de uma sociedade de outro tipo, de responsabilidade limitada ou ilimitada". BASSO, 1998. p. 41-42.

27 Para maior aprofundamento no estudo do Groupement d'Interêt Economique, recomenda-se a leitura de: MEIRELLES, Isabel. Os novos institutos societários de Direito Comunitário: 0 Agrupamento Europeu de Interesse Econômico, a Sociedade Européia. Porto: Elcla, 1992.
} 
no Mercosul, bem como em outros mercados. Atribui-se, ante o exposto, a Decisão n. 9 03/1991 o caráter inovador no incentivo para o aparecimento de um número cada vez maior de empresas que queiram se associar com outras ${ }^{31}$. Nessa perspectiva, começaram a aparecer novos meios de realizar a integração ou concentração das empresas para atender a necessidade crescente de expansão e de união empresarial, dentre os quais destaca-se a joint venture, figura jurídica que engloba as alianças estratégicas tais como o consórcio, a fusão, a aquisição, entre outras.

B - Os elementos caracterizadores da existência das Joint Ventures no caso concreto

Em face da problemática consistente na inexistência de um conceito definitivo, claro e absoluto do que entendia-se por joint venture, os tribunais e doutrinadores norteamericanos resolveram defini-la partindo da análise dos casos concretos, nos quais procuravam identificar os elementos tidos como caracterizadores daquele instituto.

Os elementos apontados pela jurisprudência e doutrina anglo-saxã, e que caracterizam uma joint venture, foram apontados por Luiz Olavo Baptista ${ }^{32}$ em festejado estudo, figurando entre eles: “a) a reunião dos participantes em uma empresa - ou uma comunidade de interesses divididos entre os participantes em um ou mais projetos;

b) um motivo, quase sempre o lucro, que leva os participantes a participarem da empresa; c) um acordo para a gestão da joint venture que disciplina o exercício dos controles; d) esse acordo deve ter os elementos de um contrato; e) a motivação e o interesse das partes em relação à empresa devem ser claros; assim como, f) a forma de distribuição dos lucros se a empresa visa o lucro para si e não para outras empresas."

Importante lição sobre as características das joint ventures é formulada por Sergio Le Pera ${ }^{33}$, uma das maiores autoridades latino-americanas neste assunto. Em notável estudo sobre cooperação empresarial, o autor propóe as características básicas e gerais das joint ventures, a saber: "el carácter 'ad hoc'; contribuiciones y 'comunidad de intereses'; búsqueda de utilidad común; contribuición a las perdidas; recíproca facultad para representar y obligar al otro ("mutual agency"); control conjunto de la empresa". Sobre algumas delas, já que certas características falam por si só, a seguir, serão tecidos alguns comentários para melhor entender-se sua operacionalidade, sempre tendo como parâmetro os ensinamentos lançados pelo referido autor, bem como utilizados os casos por ele citados.

\footnotetext{
${ }^{28}$ Acerca da utilização das joint ventures na Comunidade Européia discorrem LAMY FILHO, Alfredo; e PEDREIRA, José Luiz Bulhōes. A Lei das S.A. Rio de Janeiro: Renovar, 1992. p. 98. ${ }^{29}$ GAMBARO, 2000. p. 86. Sobre a supranacionalidade de instituições da Comunidade Européia aconselha-se a leitura de: JIMENEZ, Martha Lucia Olivar. La compreensión del concepto de Derecho Comunitário para una verdadera integración en el Cono Sur. Revista de Direito das Faculdades Metropolitanas Reunidas. São Paulo, v. 10, n. 16, p. 103-148, 1996; CAMINHA, Maria do Carmo. A
} 
Quanto ao seu caráter ad hoc, enfatiza Le Pera que é da natureza da joint venture sua limitação a uma aventura particular, ou seja, a um projeto único e específico. Isso, contudo, não implica, necessariamente, duração curta ou execução imediata $^{34}$.

No que tange às contribuições e "comunidade de interesses" entre os participantes do empreendimento específico, o autor assevera que a investigação final sobre a existência ou não de joint venture deve dirigir-se à verificação de que as partes tenham unidos seus bens, interesses, habilidades e riscos, de tal maneira que suas respectivas contribuições estejam unificadas com vista aos fins da aventura particular, bem como as contribuições das partes sejam aportadas na confiança ${ }^{35}$ de que cada uma delas atuará em benefício comum ${ }^{36}$ e como motivação para que o façam ${ }^{37}$.

Em relação à contribuição entre todos os venturers para as perdas da atividade desenvolvida pela joint venture, cumpre frisar que não se configura em pressuposto essencial para a existência de tal instituto, porquanto se pode estabelecer que os prejuízos serão suportados por apenas parte deles, em que pese a participação de todos quanto às utilidades ${ }^{38}$. Ressalte-se, porém, que este acordo não teria eficácia perante terceiros.

No que diz respeito à representação e obrigação dos participantes, em regra geral, pode-se dizer que um membro da joint venture possui a faculdade de obrigar aos outros e sujeitá-los à responsabilidade perante terceiros em questóes que estejam estritamente dentro do âmbito da associação ${ }^{39}$. O princípio da "mutual agency" faculdade acima referida - é sujeito a importantes restrições, como o caso da má-fé.

Por fim, quanto ao controle da empresa, em caso de joint venture societária, Le Pera explica que "tenga o no la facultad de administrar la operación y obligar a los copartícipes, un joint venturer debe tener alguna forma de control y dirección sobre el proyecto, aunque delegue el ejercicio de ese control en los demás partícipes”. Ou seja, não obstante seja a posição igualitária e o controle da empresa essencial para a formação da joint venture, qualquer de seus participantes pode delegar esse controle a outro, sem que perca sua condição de -co-venturer ${ }^{40}$. Infirmando o termo "controle" utilizado pela

questão da soberania e da supranacionalidade na Comunidade Européia. Revista de Derecho del Mercosur. Buenos Aires: La Ley, v. 3, n. 6, 2000; OMBRETTA, Pacilio. La Corte de Justicia de la Comunidad Economica Europea. Buenos Aires: Depalma, 1989; RODAS, João Grandino. Sociedade comercial e Estado. Sāo Paulo: Saraiva, 1995; VENTURA, Deisy de Freitas Lima. A ordem jurídica do Mercosul. Porto Alegre: Livraria do Advogado, 1996; CASELLA, Paulo Borba Comunidade Européia e seu ordenamento jurídico. São Paulo: LTr, 1994; MORADONATO, Cecília Judith. EI Parlamento de la Europa Comunitária: organización y funcionmento. Boletín Mexicano de Derecho Comparado. Mexico: UNAM, n. 98, 2000.

${ }_{30}$ Órgão de cúpula e responsável pela condução política do processo de integração e a tomada de decisōes para assegurar o cumprimento dos objetivos estabelecidos pelo Tratado, para lograr a constituição final do mercado comum. (Protocolo de Ouro Preto, artigo $3^{\circ}$ ). É composto pelos Ministros das Relaçōes Exteriores e pelos Ministros da Economia dos Estados Partes. Suas manifestações são através de Decisōes.

${ }^{31}$ COSTA, Lígia Maura. Estratégias de integração entre empresas no âmbito do Mercosul: 0 exemplo das joint ventures. Estudos Jurídicos, São Leopoldo, v.26, n. 67, maio/ago, 1993. p. 128- 129.

${ }^{32}$ BAPTISTA, Luiz Olavo. A Joint Venture: uma perspectiva comparatista. Revista de Direito Mercantil, São Paulo, n. 42. abr./jun. 1983. p. 44. 
grande maioria dos autores, Alfrefo Lamy ${ }^{41}$ dispara: "constitui ponto essencial da forma associativa o fato de todos os sócios participarem da gestáo. Não ocorre, portanto, o elemento substancial do conceito de controle, ou seja, o poder de gerir por conta própria interesses de terceiros."

Nesse sentido vai a crítica ao termo "controle" utilizado por Le Pera. De fato, na joint venture, não há controle, na acepção da palavra, de qualquer dos sócios, que, na verdade, exercem em comum a gestáo da sociedade. $O$ controle pressupóe poder de um em detrimento de outro, o que vai de encontro as próprias características e finalidades que induzem os agentes econômicos a utilizar esta forma de cooperação empresarial.

Indubitavelmente, é árdua a tarefa de classificar um operação empresarial conjunta como sendo, ou não, joint venture. Vê-se, a partir da observação das características gerais apontadas por Le Pera, que suas configuraçóes nos casos concretos demanda uma análise subjetiva das intenções dos partícipes quando da associação.

\section{C - A taxionomia dessa espécie particular de relação jurídica}

No que tange aos modelos contratuais, se faz conveniente distinguir as motivaçōes que dão origem aos acordos empresariais para se chegar ao tipo de joint venture mais adequado ao caso concreto.

As joint ventures podem ser divididas em quatro gêneros, de acordo com as características e peculiaridades da criação e funcionamento da empresa: a) pela nacionalidade das empresas que as compóem - nacional ou internacional -; b) pela sua duração - transitórias ou permanentes -; c) pela participação financeira dos co-venturers - equity ou non equity -; e, d) pela sua forma - societária ou contratual -, cada qual com determinadas características peculiares à criação e ao funcionamento do negócio.

De maior relevância é a distinção do ponto de vista formal, quando as joint ventures internacionais dividem-se em: societárias, se da associação, e de acordo com as leis do país de atuação, resultar a criação de uma nova empresa, com nova e distinta personalidade jurídica em relação às empresas participantes; e contratual, se constituída uma cooperação entre empresas, cuja a intenção é realizar um projeto ou empreendimento comum específico, regida unicamente por contratos de associação acordo base e acordos satélites ${ }^{42}$.

Na joint venture societária, também chamada de "companhia joint venture" ou “corporate joint venture", as empresas participantes do negócio comum e específico desejam criar uma nova empresa, separada das suas já existentes, que consistirá em sociedade empresária com personalidade jurídica autônoma e patrimônio próprio ${ }^{43}$.

\footnotetext{
${ }^{33}$ LE PERA, 1984. p. 74-77.

34Jurisprudência norte-americana: “U.S. v. Standard Oil of California”, 1957, 155 F. 121.

${ }^{35} \mathrm{Na}$ opinião de José León Barandiarán Hart, não se pode esquecer que a relação existente entre os partícipes da joint venture não tem característica unicamente de intuitu personae, senāo que,
} 
Nesses casos, a legislação do país escolhido regulamentará a constituição da nova sociedade, administração dos negócios, processo societário e tributário. ${ }^{44}$ Frise-se que a joint venture, em razáo de sua total flexibilidade, pode ser enquadrada em qualquer tipo societário previsto no ordenamento jurídico interno do lugar de sua atuação. Os tipos societários que mais comumente incorporam o projeto são as sociedades anônimas (S.A. - Lei n. $^{\mathrm{o}}$ 6.404/76), preferidas por quem deseja excluir sua responsabilidade subsidiária pelos possíveis débitos da nova sociedade, e as sociedades de responsabilidade limitada (Ltda. - Lei n. 3.708/19), cada qual com suas peculiaridades legais que deverão ser atendidas na constituição da joint venture, sendo a responsabilidade limitada ao capital subscrito ou à participação na sociedade, respectivamente. Porém podem ser utilizadas, também, outros tipos societários disciplinados no Código Comercial, tais como as "sociedades em nome coletivo", "sociedades em comandita simples" (arts. 325 e 326 do Código Comercial) e as "sociedades de capital e indústria", todas consideradas sociedades de pessoas.

A sociedade criada através da constituição de uma corporate joint venture será sempre nacional, independentemente do montante de participação societária estrangeira, que poderá ser majoritária ou minoritária ${ }^{45}$. $\mathrm{O}$ acordo fundamental que dá origem ao empreendimento conjunto é o contrato de joint venture, seguido, posteriormente, do estatuto ou contrato social da empresa a ser constituída, entre outros $^{46}$, chamados acordos-satélites.

Como visto anteriormente, a finalidade da associação constituída para a realização de um empreendimento comum específico, bem como as características da legislação aplicável sobre a sociedade, são os fatores que determinarão o tipo de joint venture a ser escolhido, uma vez que, em determinados casos, a criação de uma terceira empresa não é somente recomendável, senão necessária.

Destarte, "se o projeto requer investimento significativo em bens do ativo fixo (por exemplo, em plantas, equipamentos), cuja amortização haverá de ocorrer de maneira mais ou menos prolongada, a criação de uma nova sociedade ad hoc não é somente aconselhável, senão que, em alguns casos, provavelmente necessária. ${ }^{47 "}$ ' Caso típico em que se faz necessária a criação de uma terceira empresa para a execução do projeto ou empreendimento é o da instalação e operação de planta industrial de manufaturas.

mais ainda, seu substrato essencial é a confiança recíproca que contorna a relação. HART, 1988. p. 37.

${ }^{36}$ Ainda sobre as características do modelo associativo em comento, Maristela Basso faz interessante comentário quando afirma que o dever de lealdade é válido somente para as operações abrangidas pelo ajuste, de forma que relativamente a outras operações fora do âmbito deste, podem os participantes ser competidores entre si. BASSO, 1998. p. 42.

${ }^{37}$ Nesse sentido, jurisprudência internacional: "Hasday v. Barocas", 115, N.Y.S. 2d, 209, apud LE PERA, 1984.

${ }^{38}$ Nesse sentido, jurisprudência internacional: "James v. Herbert", 149 Cal., 171, F 2d, 101 , 
Sobre a opção pela joint venture societária, Maristela Basso ${ }^{48}$ é enfática ao afirmar que "a opção pela criação de uma nova empresa é geralmente motivada pelo suporte institucional que essa proporciona às associações de duração relativamente longa." Linhas após complementa: "a opção pela criação de uma entidade jurídica separada, dotada de personalidade jurídica, se dá sobretudo pela necessidade de responder às peculiaridades do país no qual se pretende operar em uma relação associativa estável.”

Em síntese, são características das joint ventures societárias, e que as diferem das joint ventures contratuais: a) a criação de uma nova empresa, com personalidade jurídica e patrimônio distintos das pessoas (físicas ou jurídicas) que as compõem; b) sua estrutura mais rígida, implicando maior compromisso entre as partes; c) a ocorrência de aporte de capitais, traduzido em investimento mais significativo; d) sua natureza jurídica que não precisa ser necessariamente limitada a um empreendimento; e) a maturação do negócio a médio ou longo prazo; e, f) a expectativa de lucros ${ }^{49}$.

Em que pese a maior utilização das joint ventures societárias no $\mathrm{Brasil}^{50}$, bem como em outros países da América Latina, como México, Argentina e Peru, a prática internacional, em geral, tem mostrado uma preferência pela joint venture contratua $P^{51}$.

A preferência pelas joint ventures contratuais, na seara internacional, remonta à problemática consistente na conciliação da estrutura societária regida pelas normas de ordem pública com a vontade das partes que desejam contratar por meio de corporate joint ventures, além da incerteza causada pela possibilidade de eventual litígio acerca da validade dos pactos e de cláusulas estatutárias atípicas elaboradas pelas partes.

A característica principal da joint venture contratual reside no fato de representar uma associação de interesses, na qual os riscos são partilhados, sem subordinação societária - formação de uma terceira pessoa jurídica -, normalmente sem contribuição de capital, mas visando os objetivos comuns ${ }^{52}$.

A opção por esta espécie de joint venture, de acordo com Carlos Alberto Bittar ${ }^{53}$, resume-se à necessidade de ampliação de mercados, à limitação dos riscos de concentração, e à excessiva oneração social e tributária de atividades produtivas.

Não se forma uma sociedade com personalidade jurídica diversa das empresas participantes, e sua natureza é, via de regra, temporária ou específica. É instrumento contratual de grande elasticidade, já que alterável segundo as exigências do

apud LE PERA, 1984

${ }^{39}$ Sobre a recíproca faculdade de representar entre os participantes da joint venture versou o caso “Rae v. Cameron", 114 2d, 1060, apud LE PERA, 1984. p. 76.

${ }^{40}$ Caso norte-americano no qual se estabeleceu a faculdade de um membro delegar sua parcela de controle real de operação da joint venture a outro é o "Shell Oil Co. v. Prestidge", 249 F2d, 413, apud LE PERA, p. 77.

${ }^{41}$ LAMY FILHO, PEDREIRA, 1992. p. 414.

${ }^{42}$ Consoante ensinamentos de RIBEIRO, Marilda Rosado de S. Joint-Ventures Internacionais material distribuído no Curso de Pós-Graduação em Comércio Exterior e Negócios Nacionais e Internacionais, Porto Alegre, 1999. p. 29-30.

${ }^{43}$ LOBO, 1995, p.81.

${ }^{44}$ Nesse sentido COSTA, L., 1993.p. 130-131. 
momento ${ }^{54}$, de modo a prevenir possíveis dificuldades oriundas das mudanças econômicas e políticas do país de atuação.

A joint venture contratual é utilizada em maior escala pelas empresas petrolíferas, sendo que o instrumento de sua formação é conhecido por "Joint Operating Agreement" ${ }^{\prime 35}$. Geralmente, no entanto, é constituída por um acordobase, ao qual seguem vários acordos-satélites que regulam, entre outras questões, a representatividade, prestação de serviços, distribuição, assistência técnica, licença de marcas e patentes, know-how.

Não há como se negar que as joint ventures contratuais estão muito mais calcadas na confiança e boa-fé entre os participantes do empreendimento comum do que em estruturas rigidas pertinentes ao modelo societário.

No Brasil, é lícito afirmar que o modelo contratual é regulado pela Lei n.․․ 6.404/ 76 que, nos arts. 278 a 294, disciplina os consórcios" ${ }^{56}$. As "sociedades em conta de participação" (arts. 325 a 328, do Código Comercial) também se prestam a abrigar essa espécie de joint venture.

Resumidamente, podem-se apontar como características elementares do modelo associativo contratual, ajustando-se, evidentemente, o contrato de joint venture a cada caso concreto: a) a limitação do objetivo a um empreendimento determinado; b) o caráter eminentemente contratual e não institucional; c) a formalização por meio de contrato; d) a intenção explícita de criar a joint venture vinculada ao objeto; e) a autonomia restrita aos limites fixados pelo acordo originário; f) a obrigação de lealdade entre os contratantes; g) a presença de risco; $h$ ) a gestão e controle conjuntos; i) a capacidade de cada participante agir pelos demais, no âmbito do objeto; e, j) prazo de duração limitado ${ }^{57}$.

D - Vantagens e motivações que induzem à utilização das joint ventures internacionais

\footnotetext{
45 Vide Maristela Basso que sobre o tema assinala, citando Enrique Zalvidar: "A inserção da joint venturo como moio de atuação inclircta do sociecade estrangeira no Brasil não implica o surgimento cie um tipo jurídico novo, como já se disse, mas sim um mecanismo novo e eficaz para a execução de cerias regcciações mercantis, industriais, financeiras, etc.". BASSO, 1998. p. 79.

4E Sobre oe inumentos jurídicos necessários para a constituição das corporale joint venture, vide LAMY FILHO, PEDREIRA, 1992. p. 34.

${ }^{47}$ Nesse seritido opina LE PERA, 1984. p. 84.

¿DASSO, i. 00 . p. 81.

49 As principuls características das joint ventures societárias foram retiradas das seguintes obras de: LUBO, C.A. da Silveira. As Joint Ventures, 1995. p. 81-84; LUPÁTELLI JÚNIOR e MAFTINS. Jofrt vendite - aspectos legais e estratégices, 1999. p. 198-199, COSTA, Estratégias de integraçäo antre empresas no âmbito do hiercosul - o exemplo das joint ventures, 1993. $p$. 130-132.

50Nesse sentuo BASSO, 1998.p. 54; e LUPATELLI JÚiviOH, MARTINS, 1999.p. 203.

51 Vide SIMENGER, 19998. p. 403.

${ }^{52}$ Nesse diapasão COSTA, L., 1993. p. 131.

${ }^{53}$ BITTAR, Carlos Alberto. Contratos comerciais. 2.ed. Rio de Janeiro, Forense Universitária, 1994. p. 213.
}

${ }^{54}$ STRENGER, 1998. p. 403 
Inúmeras são as vantagens proporcionadas pela associação entre empresas de diferentes países na forma de joint ventures, razão pela qual várias operaçōes desta espécie foram realizadas no mundo todo ${ }^{58}$, no país e com a participação de empresas brasileiras no exterior, principalmente na seara intramercosuli ${ }^{59}$.

É o caso das joint ventures típicas de investimentos nos países do Terceiro Mundo, onde o parceiro do país desenvolvido contribui com o capital e com a tecnologia, e o parceiro do país em desenvolvimento participa com os meios de acesso ao mercado que, de outro modo, poderiam ser inacessíveis ao estrangeiro ${ }^{60}$.

Motivo determinante para a formação ou constituição de uma joint venture está no fato de a moderna joint venture, tal como sua antecessora, vislumbrar campo livre e desimpedido para a autonomia da vontade e, assim sendo, para o exercício da imaginação criadora dos homens de negócios e advogados. Conseqüência lógica disso, aparece uma das suas mais evidentes vantagens, qual seja, a inserção das empresas em novos mercados, haja vista que as joint ventures internacionais são dotadas de notável poder de penetração no mercado internacional ${ }^{61}$, principalmente em função de sua grande flexibilidade, adaptando-se às peculiaridades das legislações e práticas comerciais de cada país que ainda não a tenha prevista no ordenamento jurídico interno seu ${ }^{62}$.

A associação entre empresas estrangeiras é, sem dúvida alguma, vantajosa na medida em que seu objetivo fundamental é a constituição de uma empresa, nova ou não, mais forte e moderna para fazer frente à concorrência. A otimização, criação e a expansão da capacidade de produção por intermédio do incremento de novas tecnologias e técnicas administrativas e produtivas, bem como o melhoramento no nível dos produtos e serviços são outros fatores determinantes para a associação empresarial através de joint ventures ${ }^{63}$.

A transferência da mais alta tecnologia ${ }^{64} \mathrm{e}$ know-how assimilado pelo empresário e o país hospedeiro da joint venture traduz uma das maiores vantagens dessa espécie de associação, porquanto viabiliza a melhoria e diversificação dos serviços, bens e produtos da marca das empresas locais, aumento de sua produção e, acima de tudo, torna-os, o empresário e o país anfitrião, mais competitivos no cenário internacional.

De outra banda, a associação empresarial por meio de joint venture pode ser vantajosa para o empresário nacional que pretende investir no exterior quando se

\footnotetext{
${ }^{55}$ No material de Marilda Rosado, é dado maior ênfase às joint ventures contratuais, operadas pelas empresas petrolíferas em seus contratos de açāo conjunta internacional. RIBEIRO, 1999. p. 30 .

${ }^{56}$ Interessantes questões acerca do consórcio no direito brasileiro são levantadas por LOBO, 1995.p. 82. e RIBEIRO, 1999. p. 6, 10-11. O primeiro lembra que, em princípio, não há solidariedade entre os consorciados, respondendo estes apenas pelas obrigaçōes que cada um contraiu. Já a segunda, citando ensinamentos de Túlio Ascarelli, sustenta que no consórcio não há constituição de patrimônio em separado, respondendo todos ilimitadamente pelas dívidas que tenham assumido, coletivamente, perante terceiros. Linhas após, a referida autora traz à baila o entendimento de Pedro Paulo Cristófaro, para quem nos grupos não personificados, como os consórcios, os efeitos dos atos jurídicos praticados pelos seus representantes incidem imediatamente sobre o patrimônio destes, uma vez que não podem recair sobre uma pessoa jurídica que não existe.
} 
vislumbra a oportunidade de fruição de recursos e aproveitamento dos canais de distribuição já operantes no mercado estrangeiro ${ }^{65}$.

As joint ventures são classificadas como forma de investimento indireto no país em que se opera, onde se associam os capitais estrangeiros ao capital nacional, rateando-se, assim, os riscos dos investimentos ${ }^{66}$. Por se tratarem de investimentos estrangeiros, não há como negar-se, são benéficos à economia do país hospedeiro que, por sua vez, pode até mesmo disponibilizar incentivos fiscais para que outras empresas invistam no país. Conclusão a que se chega é que o país de atuação da joint venture internacional será beneficiado pela modernização de seu parque industrial proporcionada pela chegada de nova tecnologia, bem como pelo crescimento de seu empresariado, que poderá atuar competitivamente no mercado internacional, com conseqüente aumento das exportações nacionais.

Não se pode olvidar dos ensinamentos de Sergio Le Pera que, com o brilhantismo e clareza que lhe são peculiares, discorre sobre as vantagens das joint ventures internacionais desde o ponto de vista da empresa estrangeira e da empresa local. Sustenta o ínclito autor que:

"desde el punto de vista de la empresa estranjera, contar con el conocimiento del mercado y del ambiente cultural, político y de negocios del país de actuación, y en ocasiones complacer los sentimientos nacionalistas o regulaciones legales de ese país. Desde elángulo de la empresa local, contar com la capacidad tecnológica, empresaria y financiera de la otra. ${ }^{67}$ "

É muito importante para o empresário estrangeiro, que deseja "aventurar-se" por meio de investimento ou negócio fora de seu território, familiarizar-se, de algum modo, com mercado no qual estará atuando, com a cultura das pessoas que naquela localidade movimentam o mercado, com a política implementada no local de atuação, e, acima de tudo, com a legislação a qual estará sujeito em sua “empreitada". É nesse contexto que surge a opção pela joint venture, até mesmo como forma de se evitar futuros imprevistos ocasionados pelo despreparo e desconhecimento dos aspectos atinentes a localidade de atuação da empresa estrangeira.

Cumpre reforçar que a utilização cada vez em maior escala deste tipo de operação ou cooperação empresarial está calcada, mormente, no fato de ser bastante flexível, porquanto se adapta a qualquer tipo de negócio e legislação, e, também, por ser, na grande maioria das vezes, mais econômica que as formas tradicionais de integração ou concentração de empresas, tais como o consórcio de empresas, a fusão, a aquisição.

Não obstante a evidência das vantagens aqui apontadas, é extremamente necessário fiscalizar a constituição ou formação das joint ventures internacionais no país, com vista a evitar ou reprimir que, por meio da concentração de empresas, se atente contra a ordem econômica nacional em casos de abuso do poder econômico (artigo 173, § 4º, da Constituição Federal).

${ }^{57}$ As características acima expostas são enumeradas por LUPATELLI JÚNIUOR, MARTINS, 1999.p. 197. 
III - O procedimento de notificação e aprovação das Joint Ventures Internacionais conforme os ditames da Lei Antitruste Brasileira

O denominado controle ou crivo prévio exercido pela Autoridade Antitruste brasileira (Conselho Administrativo de Defesa Econômica - CADE) no processo de formação e aprovação dos atos de concentração empresarial é regido pelos preceitos legais contidos na Lei Federal n. 8.884/94, também conhecida como Lei Antitruste Brasileira. Cabe ao CADE, portanto, apreciar as implicações de mercado e sociais dos atos de parceria empresarial sob a égide concorrencial da supracitada lei antitruste.

A referida lei, que regula especificamente a matéria, não veda ou próibe a parceria empresarial, mas condiciona, dependendo da situação, a sua formação ou constituição à aprovação e registro pelo CADE. Mais precisamente, a competência atribuída ao $\mathrm{CADE}$ para apreciação dos chamados atos de concentração empresarial, em momento anterior a sua formação, é estabelecida no caput do artigo 54 da Lei n.o 8.884/94 que reza, in verbis:

“Art. 54 - Os atos, sob qualquer forma manifestados, que possam limitar ou de qualquer forma prejudicar a livre concorrência, ou resultar na dominação de mercados relevantes de bens ou serviços, deverão ser submetidos à apreciação do CADE."

Percebe-se, da leitura do artigo transcrito, que a atuação do CADE na formação de concentrações empresariais justifica-se sempre que se verificar possibilidade de prejuízo ou limitação à livre concorrência, ou quando destas parcerias puder resultar dominação de mercados relevantes de bens ou serviços. Isto é, tudo em conformidade com o disposto no artigo $173, \S 4^{\circ}$, da Constituição Federal que, procurando evitar a prática de tais atos, propugna a repressão ao abuso do poder econômico.

Resta claro que o procedimento de notificação e aprovação das joint ventures internacionais encontra-se fulcrado na análise dos efeitos potenciais de concorrência e de mercado da parceria almejada ${ }^{68}$. Nesse sentido, é válido dizer que, em regra

\footnotetext{
${ }^{58}$ Vários casos de joint ventures internacionais entre empresas do mundo todo são citados por Maristela Basso, em sua obra, no capítulo "Joint Ventures segundo setores de atividade". BASSO, 1998. p. 62-68. ${ }^{59}$ Exemplos de joint ventures no país e no Mercosul: AT\&T (Estados Unidos) com SID TELECON (Brasil) com vista a fabricação, no país, de produtos na área de telecomunicações; MESA ELETRÔNICA (Brasil) e SINUELO INTER TRADING (Brasil) com ESIMET (Argentina) - constituiram nova empresa em Curitiba, a TERMOGAS, para fabricação de equipamentos de produção de água quente e calefação; LACTA BRASIL com GEORGALOS (Argentina) - contrato para auxílio tecnológico e de distribuição; CELITE (Brasil) com PIAZZA (Argentina) - joint venture para fabricação e distribuição conjunta de sanitários; entre outros. ${ }^{60}$ Vantagem apontada por COSTA, L., 1993. p. 131-132.

${ }^{61}$ Essa a principal vantagem apontada por LAMY FILHO, PEDREIRA, 1992. p. 98.
} 
geral, cabe aos próprios agentes econômicos envolvidos na transação verificar e analisar os efeitos potenciais e reais de suas parcerias, tendo em vista a estrutura do mercado de atuação e a necessidade de evitar-se prejuízo a saudável atividade concorrencial, concluindo pela necessidade de submete-las, ou não, ao crivo prévio do $\mathrm{CADE}$. Algumas parcerias, no entanto, estâo sujeitas à notificação obrigatória à autoridade antitruste como condição sine qua non para operacionalização. Nesse caso, como veremos no decorrer deste trabalho, a lei estabelece no artigo 54 , $\S 3^{\text {o }}$ parâmetros caracterizados por limites quantitativos que, uma vez verificados, levarão à necessidade de submissão incontinenti da parceria empresarial à aprovação do CADE.

Várias são as formas de integração ou concentração ${ }^{69}$ empresarial das quais poderão resultar limitação ou prejuízo ao princípio da livre concorrência, bem assim na dominação de mercados relevantes de bens ou serviços, sendo, portanto, passíveis de apreciação pelo CADE.

Estabelece o $§ 3^{\circ}$ do artigo 54 da Lei n.o 8.884/94 que:

"incluem-se nos atos de que trata o caput aqueles que visem a qualquer forma de concentração e conômica, seja através de fusão ou incorporação de empresas, constituição de sociedade para exercer o controle de empresas ou qualquer forma de agrupamento societário..."

A menção feita a "qualquer forma de agrupamento societário" é garantia de precaução legal contra a criatividade jurídica dos advogados e agentes econômicos. Exatamente nesse contexto conclui-se que, dentre as formas de agrupamento societário

\footnotetext{
${ }^{62}$ A lei comercial iugoslava de 1978 , modificada em 1984, regula expressamente a formação e funcionamento das joint ventures.

${ }^{63}$ Entendimento externado pelos autores do anteprojeto que se converteu na Lei $n .{ }^{\circ} 6.404 / 76$, LAMY FILHO, PEDREIRA, 1992. p. 363.

${ }^{64}$ Para maiores informações acerca do tema joint ventures e transferência de tecnologia, vide GRAU, Eros Roberto. Joint ventures e transferência de tecnologia: Lei de Informática. Revista de Direito Mercantil, Industrial, Econômico e Financeiro, São Paulo, v.79, 1990. p. 5-16.

${ }^{65}$ Nesse sentido STRENGER, 1998. p. 401.

${ }^{66}$ Maristela Basso discorre sobre as diferentes formas de atuação das empresas alienigenas no país, dentre as quais aparecem os investimentos indiretos ocasionados pela formação de joint ventures.BASSO, 1998.p. 77-80.

${ }^{67}$ LE PERA, 1984. p. 88

${ }^{68}$ Sobre essa assertiva é esclarecedora a explicação promovida por Tércio Sampaio Ferraz Júnior, para quem "os atos que devem ser submetidos a controle prévio são os que, potencialmente, têm condições de afetar a estrutura concorrencial de um mercado relevante. Práticas que manifestam meras estratégias comportamentais (aumento de preço, retirada de um produto da linha de fabricação, suspensão de um fornecimento reiterado etc.) não precisam ser comunicadas. Por sua vez, a simples inclusāo de uma cláusula de não-concorrência num contrato já é motivo de comunicação. A proibição mútua de nāo-concorrência é prática que pode afetar a estrutura do mercado. Isto não quer dizer, porém, que qualquer contrato que a preveja deva ser comunicado. A lei se preocupa com atos que afetem a estrutura de um mercado relevante." Apud PROENÇA, José Marcelo Martins. Concentração empresarial e o direito da concorrência. São Paulo: Saraiva, 2001. p. 81.
} 
que refere a lei estão, obviamente, as joint ventures internacionais, originadas justamente da criatividade jurídica, que ao presente trabalho interessam de maneira particular.

Da análise do caput do artigo 54, percebe-se que ao CADE não interessa examinar a forma do ato, se joint venture ou não, mas unicamente verificar se essa joint venture internacional, por exemplo, poderá traduzir-se em concentração do poder econômico que venha a falsear, de qualquer forma, a livre concorrência, ou resultar na dominação de mercado relevante, práticas tidas como infrações à ordem econômica pela própria Constituição Federal ${ }^{70}$. A concentração de poder verifica-se quando o poder econômico que duas ou mais empresas possuem separadamente concentra-se no momento em que praticam ato previsto no caput do artigo 54 , deslocando-se o poder para um mesmo centro ${ }^{71}$.

Para tanto, ou seja, para auxiliar no processo de controle preventivo realizado pelo CADE, a Lei n. $.^{\circ} 8.884 / 94$ impóe, em seu artigo 54 e $\$ \S$, uma série de indicadores e exigências que deverão ser satisfeitas pelos agentes econômicos e verificadas pelo próprio $\mathrm{CADE}$. Essas condições e requisitos serão, a partir de agora, objeto de análise individual.

Muito embora se reconheça as evidentes vantagens obtidas pelos agentes econômicos que empreendem ação conjunta empresarial na forma de joint venture internacional (vide Capítulo I, subtítulo D), inúmeras vezes, o fenômeno da integração de empresas, seja na forma vertical ou horizontal, ao invés de favorecer o consumidor, como também seria de se esperar, promove verdadeira alteração na estrutura do mercado, comprometendo a própria concorrência entre os diversos agentes econômicos ${ }^{72}$,

Em conseqüência disso, alguns atos de integração empresarial devem ser, necessariamente, levados à apreciação do CADE que, tendo em conta as disposiçóes da Lei Antitruste brasileira (artigo 54), os aprovarão ou não. Seja no momento de sua formação, ou momento posterior, a joint venture, uma vez caracterizada a possibilidade de infração à ordem econômica, sujeitar-se-á, incontinenti, à Lei Antitruste brasileira ${ }^{73}$.

\section{A - Os prazos do procedimento de notificação}

O artigo 54 estabelece o procedimento è os prazos aplicáveis ao processo de notificação e revisão das joint ventures internacionais. A notificação das joint ventures

\footnotetext{
${ }^{69}$ Para Luiz Olavo Baptista a noção jurídica de concentração é bem mais completa que a econômica, na qual enquadram-se as fusões, as incorporações, os grupos, os consórcios e a tomada ou exercício de controle. Segundo o autor, juridicamente, trata-se da "concentraçãointegração, e nela se reúnem todas as formas de concentração (econômica) e de integração (econômico-administrativa). Assim, no conceito jurídico de concentração englobam-se todas as formas de crescimento, integração, quase interposição, simbiose, agregação, nas quais se possa manifestar a tendência da empresa de reunir capacidades econômico-tecnológicas para o
} 
internacionais que se enquadrarem nas disposições do caput do artigo 54 e seu $\S$ 3을 deverá ser feita a Secretaria de Direito Econômico do Ministério da Justiça ${ }^{74}$ (SDE) que, por sua vez, enviará cópias da documentação submetida pelas partes interessadas a Secretaria de Acompanhamento Econômico do Ministério da Fazenda (SEAE).

Feito isso, a SEAE deverá providenciar um relatório técnico para a SDE dentro de 30 dias. A SDE, então, no prazo de 30 dias do recebimento de tal relatório, fará uma recomendação ao $\mathrm{CADE}$. $O$ processo, neste ponto, será transferido ao $\mathrm{CADE}$, o qual deverá tomar sua decisão dentro de no máximo 60 dias ${ }^{75}$, excepcionando-se os casos de suspensão do prazo pela pendência de documentação requerida ${ }^{76}$. Caso o CADE não tome sua decisão dentro do prazo previsto em lei, a joint venture será considerada automaticamente aprovada pela autoridade antitruste ${ }^{77}$.

Eis aqui o atestado mais eloqüente dos equívocos verificados na lei de proteção à concorrência. Ora, muito embora a evidente vantagem decorrente desta determinação para os particulares, ao realizar-se uma interpretação teleológica ${ }^{78}$ da lei em questão, que leva em conta sua finalidade - a prevenção e a repressão às infraçóes contra a ordem econômica -, não se poderia cogitar em autorização automática do ato por decurso de prazo para a tomada da decisão ${ }^{79}$.

É importante salientar que o prazo é de 60 dias corridos, não importando se úteis ou não. Ademais, não poderá ser alegado pela Administração Pública excesso de trabalho que justificaria o atraso.

O cômputo do prazo para a aprovação automática poderá ser realizado de duas formas, valendo sempre aquela que melhor beneficiar o agente econômico cujo o ato se analisa. Na primeira, como forma de evitar possível alegação de falta de protocolo no CADE, para fins de retardar o prazo estipulado em lei, leva-se em conta os prazos também destinados à Secretaria de Acompanhamento Econômico do Ministério da Fazenda e Secretaria de Direito Econômico do Ministério da Justiça, ambos de 30 (trinta) dias, em conformidade com o $\S 6^{\circ}$ do artigo 54 . Assim, ocorrerá a aprovação automática quando, transcorridos 120 dias do protocolo inaugural, não sobrevier manifestação do CADE. Na segunda, leva-se unicamente em conta o prazo de 30 (trinta) dias, contados a partir do ingresso do feito no $\mathrm{CADE}$.

aumento de seus potenciais, e que the permitam melhor posição no mercado. Concentração de empresas. Revista Forense: Rio de Janeiro, v.264, 1978. p. 55.

70 Jurisprudência do CADE: Ato de Concentração no 08012.000164/99-03. Requerentes: Du Pont do Brasil S/A e Haci Omer Sabanci ASS: "Conforme visto no Relatório, a presente operação ocorre em seguimento a Ato de Concentração já apreciado por este CADE, pelo qual se aprovou a associação entre Du Pont e Sabanci para a construção da primeira fábrica brasileira de dipping. Trata-se, agora, da aquisição de $50 \%$ do controle da Du Pont do Nordeste pela Sabanci, operação que visa à produção do tecido denominado "náilon 6", insumo para a produção de tecidos beneficiados pelo processo de dipping, de maneira que esta empresa passa também a participar de etapa anterior da cadeia de produção de pneus. O mercado relevante desta operação foi definido pelas requerentes, pela SEAE, SDE e Procuradoria Geral do CADE como 
Uma vez aprovado automaticamente o ato por decurso do prazo, torna-se impossível a revisão da aprovação, uma vez que, se possível fosse, tornar-se-ia ineficaz a parte final do preceito contido no $§ 7^{\circ}$ do artigo 54 da Lei n. $^{\circ}$ 8.884/94. Seria "o mesmo que não admitir essa modalidade específica de aprovação, contrariando frontalmente o previsto naquele dispositivo da lei antitruste. ${ }^{80 "}$

A legitimação automática dos atos submetidos ao controle prévio do $\mathrm{CADE}$ pode ser nefasta ao sistema econômico, porquanto toda e qualquer infração econômica futura passa a ser considerada previamente lícita. O prejuízo social, acaso realmente demonstrado, deverá ser inteiramente indenizado pelos responsáveis pela desídia ou atraso na apreciação do ato; responsabilidade esta que será objetiva em face da comunidade em geral e subjetiva em relação ao Estado ${ }^{81}$, nos termos do $\S 6^{\circ}$ do artigo 37 da Constituição Federal $^{82}$, sem prejuízo de eventual responsabilidade penal a ser verificada.

\section{B - O CADE: natureza e discricionariedade}

A Lei Antitruste brasileira, no seu artigo $3^{\text {o83 }}$, refere-se ao $\mathrm{CADE}^{84}$ como órgão judicante com jurisdição em todo território nacional, conferindo-lhe natureza jurídica de autarquia federal, inclusive com direito a patrimônio e destinação orçamentária própria. Obviamente, trata-se aqui de jurisdição administrativa, uma vez que o $\mathrm{CADE}$ não integra o Poder Judiciário, vinculado que está, de forma expressa no supracitado dispositivo legal, ao Ministério da Justiça, integrante do Poder Executivo ${ }^{85}$.

A autoridade antitruste brasileira é composta por um Presidente e seis membros conhecidos como Conselheiros, todos indicados pelo Presidente da República e aprovados pelo Senado Nacional por mandatos de dois anos, ainda que poderão permanecer no cargo por mais um mandato, por recondução. $O$ curto mandato dos conselheiros do CADE resulta em rápida e freqüente rotatividade na composição do Conselho, o que tem sido objeto de crítica especialmente por especialistas internacionais ${ }^{86}$, para quem essa rotatividade provoca a falta de um quadro permanente e profissional no CADE, bem como priva o Conselho de um grau maior de

o de fios e tecidos de náilon para reforço de pneus convencionais produzidos no Brasil. Adoto tal definição, salientando que a Sabanci não atuava neste mercado, de maneira que a sua entrada não altera o grau de concentração existente. Ante o exposto e por não vislumbrar a geração de efeitos anticoncorrenciais da operação em tela, voto pela sua aprovação sem restrições."

${ }^{71}$ PROENÇA, 2001. p. 84-87.

${ }^{72}$ Nesse sentido Newton de Lucca, em prefácio à obra de José Marcelo Martins Proença. 2001. p. XIII e XIV.

${ }^{73}$ LUPATELLI JÚNIOR., MARTINS, 1999. p. 181.

74 Artigo 54 , § $4^{\circ}$, da Lei n. 8.884/94.

${ }^{75}$ Artigo 54 , § $6^{\circ}$, da Lei n. 8.884/94.

${ }^{76}$ Artigo 54 , § 80, da Lei n. 8.884/94.

$\pi$ Artigo 54 , § $7{ }^{\circ}$, da Lei n. 8.884/94.

${ }^{78}$ Carlos Maximiliano, citando Wurzel, explica que por considerar-se o "Direito como uma ciência primariamente normativa ou finalística; por isso mesmo a sua interpretação há de ser, na essência, teleológica. O hermeneuta sempre terá em vista o fim da lei, o resultado que a mesma precisa atingir em sua atuação prática." MAXIMILIANO, Carlos. Hermenêutica e Aplicação do Direito. 18.ed. Rio de Janeiro: Forense, 2000. p. 151. 
independência em relação ao governo, levando-se em consideração o fato de que todo o Conselho pode ser substituído dentro de um período de dois anos.

Dentre as atribuições do CADE inclui-se aquela pertinente ao exercício do exame prévio de joint ventures internacionais que poderão culminar em abuso do poder econômico, eliminação de concorrência ou dominação de mercado relevante, decidindo por sua aprovação, alteração (desconstituição) ou não-aprovação. Outrossim, ao Conselho compete decidir sobre a existência de infração à ordem econômica e aplicar as penalidades previstas em $\mathrm{le}^{\mathrm{i}}{ }^{87}$. Muito embora o poder discricionário conferido pela legislação em vigor ao $\mathrm{CADE}$ na tomada de suas decisões, é importante ressaltar que a própria legislação não veta totalmente a concentração de grande poder econômico, mesmo que certos atos venham, porventura, a configurar-se em dominação de mercado relevante nos termos dos artigos 20 e 54, caput, da Lei in comento.

Portanto, é de se deixar bem claro, desde já, que à joint venture internacional é permitido a concentração de grande poder econômico, sem que com isso incorra em infração à ordem econômica, porquanto, nos termos do $\S 1^{\circ}$ do artigo 20 da lei antitruste, "a conquista de mercado resultante de processo natural fundado na maior eficiência de agente econômico em relação a seus competidores não caracteriza o ilícito previsto no inciso II" (dominar mercado relevante de bens e serviços).

Consagra-se, dessa forma, a vantagem competitiva do agente econômico, não se punindo a posição dominante por si só, mas apenas o abuso dessa posição que culmine em limitação ou restrição à livre concorrência, beneficiando-se, assim, a joint venture

\footnotetext{
${ }_{79}$ Sobre a aprovação automática, vale transcrição do comentário de João Bosco Leopoldino da Fonseca: "A complexidade da matéria, o volume dos processos e a dificuldade das questões a serem abordadas, bem como ainda a restrita estrutura desses órgãos, levam a crer que o dispositivo legal permanecerá letra morta." FONSECA, 1995. p. 150.

${ }^{80}$ COELHO, 1995. p. 130.

${ }^{81}$ Cf. POPP, ABDALA, 1994. p. 130.

${ }^{82}$ Art. $37, \S 6^{\circ}$, da Constituição Federal: "As pessoas jurídicas de direito público e as de direito privado prestadoras de serviços públicos responderão pelos danos que seus agentes, nessa qualidade, causarem a terceiros, assegurado o direito de regresso contra o responsável nos casos de dolo ou culpa."

${ }^{83}$ Art. $3^{\circ}$ da Lei n. $8.884 / 94:$ "O Conselho Administrativo de Defesa Econômica - CADE, órgão judicante com jurisdição em todo o território nacional, criado pela Lei 4.137 , de 10 de setembro de 1962, passa a se constituir em autarquia federal, vinculada ao Ministério da Justiça, com sede e foro no Distrito Federal, e atribuições previstas nesta lei."

${ }^{84}$ Criado pela primeira vez em 1945 , através do Decreto-lei $n .97 .666$, que não teve duração superior a dois meses, o CADE foi definitivamente instituído com a promulgação da Lei $n .04 .137$ de 1962 .

${ }^{85}$ Hely Lopes Meirelles refere-se ao CADE como órgão administrativo de função quase-judicial, a exemplo de outros órgãos enquadrados nesta mesma categoria, como o Tribunal Maritimo, os Conselhos de Contribuintes, dentre outros. MEIRELLES, Hely Lopes. Estudos e pareceres de direito público. São Paulo: Revista dos Tribunais, 1981. v. 4. p. 129.

${ }^{86}$ CLARK, John W. Competition Law and Policy Developments in Brazil. OECD: Journal of Competition Law and Policy, v. 2, n. 3, 2000. p. 186.

${ }^{87}$ Artigo 7 , inciso II, da Lei n. 8.884/94.

${ }^{88} \mathrm{Na}$ opinião de Marcelo Proença, existem duas formas de poder econômico: "o alcançado pelo crescimento interno da empresa, que o legitima; e o poder obtido por meio de atos de concentração que venha a expressar, ou expresse desde logo, um domínio do mercado, dando vistas que o poder de mercado obtido ensejará ou possibilitará a prática de atos abusivos, atos dotados de abuso do poder econômico." PROENÇA, 2001. p. 80-81.

${ }_{89}$ Nesse sentido, convém trazer-se à baila parte do voto proferido pela conselheira-relatora no caso Fiat $\times$ Transauto, levado à apreciação do CADE, in verbis: "Diga-se, porém, que o princípio da livre
} 
que em virtude de sua eficiência e presteza possa oferecer ao consumidor preços mais baixos pelo serviço ou produto. $O$ poder econômico ${ }^{88}$ somente poderá ser reprimido quando orientado à dominação de mercado ou na medida em que se transforma em lesão à concorrência ${ }^{89}$.

No entanto, esse dispositivo traz em seu bojo uma flagrante contradição $0^{90}$. Isso porque, ao mesmo tempo em que beneficia a empresa que obtém vantagem concorrencial de forma lícita, em funçáo de sua eficiência, o caput do artigo $20^{91}$ estabelece a responsabilidade objetiva ${ }^{92}$ do agente econômico que, por meio da constituição de joint venture internacional, por exemplo, produza os efeitos tipificados como infrações contra a ordem econômica, apontados nos incisos I ao IV, "ainda que nâo sejam alcançados".

$\mathrm{O}$ artigo 20 da lei especial, diga-se de passagem, caracterizando certas condutas como ilícitas independentemente de culpa, tem sido objeto de crítica por alguns estudiosos no assunto, que chegam a apontar a sua inconstitucionalidade. Para tanto, alegam que a Lei n. $8.884 / 94$, na esteira do artigo 20, define certas ações como ilícitos civis, obviamente. Acontece que o ilícito civil, segundo o princípio básico contido no artigo 159 do Código Civil, assenta-se na culpa, razão pela qual o mencionado dispositivo antitruste seria contrário ao ordenamento

concorrência não conduz à antijuridicidade do poder econômico. O sistema adotado pelo texto constitucional não é o da per se condemnation, mas o da regra da razão, o que vale dizer que o poder econômico só pode ser reprimido quando orientado à dominação de mercado ou quando atua de forma lesiva à concorrência." Revista do Ibrac, v. 2, n. 1, p. 82.

${ }^{90} \mathrm{~A}$ esse respeito manifesta-se Paula A. Forgioni: "Lembremo-nos, no entanto, que a concorrência, ainda que lícita, prejudica alguns agentes econômicos. Qual é, então, o limite que indica a licitude do prejuizo causado? Até que ponto deve ser suportado o exercício das vantagens decorrentes da superioridade do agente econômico? Como diferenciar a concorrência vigorosa da prática abusiva?... Atualmente, se de urna parte é quase intuitivo que a vantagem competitiva, lícita que é, deve ser incentivada mediante a aplicação das normas de tutela do livre mercado e da livre concorrência, de outra não se têm apropriados critérios gerais para determinar, na prática, a separação entre a concorrência lícita, cujos prejuizos causados a terceiros baseiam-se em uma vantagem competitiva, e a concorrência predatória. FORGIONI, Paula A. Os fundamentos do antitruste. São Paulo: Revista dos Tribunais, 1998. p. 275.

${ }^{91}$ Art. 20 da Lei n. 8.884/94: "Constituem infração da ordem econômica, independentemente de culpa, os atos sob qualquer forma manifestados, que tenham por objeto ou possam produzir os seguintes efeitos, ainda que não sejam alcançados: I - limitar, falsear ou de qualquer forma prejudicar a livre concorrência ou a livre iniciativa; II - dominar mercado relevante de bens ou serviços; III - aumentar arbitrariamente os lucros; IV - exercer de forma abusiva posição dominante."

${ }_{92}$ Sobre a responsabilidade objetiva do agente econômico preconizada na Lei Federal n. ${ }^{\circ} 8.884 / 94$, mais precisamente no seu artigo 20, sugere-se a leitura do artigo publicado por SILVA, Paulo Thadeu Gomes da. A responsabilidade objetiva na Lei Antitruste - 8.884/94: Aspectos constitucional e infra-constitucional. Revista da Procuradoria Geral da República, São Paulo, n.8, p. 264-274, 1996.

${ }_{93}$ Sobre a suposta inconstitucionalidade do artigo 20 da Lei Antitruste brasileira, merece transcrição trecho do texto elaborado por João Luiz Coelho da Rocha: "Mais flagrante, porém, e aí autorizando perceber-se logo uma patente inconstitucionalidade é a absurda tipificação dos delitos contra ordem econômica expressa nó caput do art. 20...Está-se aí definindo tipologicamente certas açōes como ilícitos. llícitos civis, naturalmente. Ora, o ilícito civil no princípio básico da lei brasileira (art. 159 do CC) assenta-se na culpa, naquele dispositivo definida. Não tem cabimento jurídico, pois, que, em afronta aos termos da Lei Complementar (como é o Código Civil, que tal força óbvia teria) a Lei 8.884 defina como ilícitos civis (comerciais, na espécie) atos não culposos. Fala-se aqui de ilícito, de tipificação de uma conduta injurídica punivel e não de criação de uma simples responsabilização patrimonial derivada do mero risco, como acontece nos casos de responsabilidade objetiva...Parece contudo inesgotável a impropriedade do legislador nesse trato da ordem econômica e sua infrações. Pois na composição tipológica daqueles ilícitos resolveu compreender atos que tenham por objeto certos efeitos nocivos ao saudável fluxo econômico, então listados, mas ainda atos que não propriamente 
jurídico ${ }^{93}$. Outrossim, o artigo 20 em comento, tendo em conta as disposições dos artigos 54, § 3얼 da mesma lei, e artigo 173 , § 4º, da Constituição Federal, seria inconstitucional tendo em vista a discrepância entre o verbo "visar", empregado nos dois últimos, se entendido como referência ao elemento volitivo do agente econômico, e a expressão "independentemente de culpa" 94.

Esta é exatamente a opinião de José Cretella Júnior ${ }^{95}$ que, analisando a possibilidade do CADE autorizar atos ou contratos que, nada obstante preencham certas condições previstas na lei especial, são prejudiciais à concorrência e, portanto, ilícitos, sustenta que o intérprete fica perplexo ao se deparar com o antagonismo existente entre as disposições dos artigos 20, inciso I, e 54 .

De fato, ao estabelecer que, "independentemente de culpa", o ato que limitar, falsear ou de qualquer forma prejudicar a livre concorrência ou a livre iniciativa, bem como resultar em dominação de mercado relevante, mesmo que não alcançados, constituirão infração contra a ordem econômica, a lei, à primeira vista não poderia abrir a exceção contida no $\S 1^{\circ}$ do artigo 20 , porquanto nitidamente incongruentes. $\mathrm{O}$ termo de qualquer forma é incompatível com a conquista de mercado legitimada posteriormente.

Melhor redação teria o artigo 20 se dispusesse serem considerados ilícitos os atos que prejudiquem a concorrência, desde que não preenchidas as condiçóes previstas no artigo 54 da mesma lei. Isso pois, se nos termos do artigo 20 , inciso I, os atos ou contratos que prejudiquem a concorrência por si só configuram-se em infrações contra a ordem econômica, cuja repressão e prevenção são objetos da própria Lei Antitruste, não haveria porque submetê-los à apreciação do $\mathrm{CADE}$, não cabendo as exceções. Porém, a lei objetiva estimular a concorrência saudável, na qual os melhores vencem, dentro das regras dojogo, é claro, e dessa forma deve ser interpretada.

Não se deve olvidar que a vantagem competitiva, ainda que "resultante de processo natural fundado na maior eficiência de agente econômico", portanto lícita, ocasiona prejuízos a outros agentes econômicos que no mesmo mercado conquistado atuam. Toda concorrência, ainda que saudável para uns, é prejudicial para outros ${ }^{96}$. Então, como se chegar ao denominador comum entre a licitude do mercado conquistado e a limitação e prejuízo que isso necessariamente provoca à concorrência dos demais agentes econômicos? O texto é, sem dúvida alguma, de um subjetivismo tremendo.

Para Paula A. Forgioni ${ }^{97}$, a forma de explicar a licitude (ou ilicitude) dos efeitos decorrentes do uso (ou abuso) da posição dominante pode ser encontrada na utilização de um critério de diferenciação na eficiência econômica, segundo o qual a "eliminação de empresas menos eficientes serviria ao propósito da Lei Antitruste, ou também, na aplicação

objetivem o alcance daquelas situações de incorreto desbalanceamento da economia mas que 'possam produzir' tais efeitos 'ainda que não sejam alcançados'. Entende-se portanto no texto legal que qualquer ato da empresa - ainda que desprovido de culpa, como vimos - que na verdade não prejudique a livre concorrência, mas que poderia eventualmente tê-lo feito, qualifica um ilicito contra a ordem econômica. $E$, certamente, invertendo toda a concepção do ato ilícito, e pervertendo a técnica mais comezinha da formação dos tipos legais, defere ao abstrato, vago, nebuloso e perigoso parâmetro da 'possibilidade' de produção de algum daqueles efeitos tidos como deletérios, a verificação da ocorrência da 
do princípio geral que condena, em nosso ordenamento jurídico, o abuso do direito. Nesse último sentido, consoante as abalizadas palavras da autora supramencionada, "a utilização do poder econômico (e do direito à liberdade econômica) apresentaria restrições se fosse efetuada de forma não adequada, reprovável ou reprovada, ilegítima ou tida como tal, rompendo o equilíbrio dos interesses em conflito ou do desvio da finalidade do direito, da sua destinação social e econômica. ${ }^{98}$ "

Em realidade, o dispositivo in focu propóe a promoção da eficiência econômica que culmine tanto na maximização da satisfação dos consumidores, como, em contrapartida, no aumento dos lucros dos produtores, mesma razão pela qual, nos termos do $\S 1^{o}$ do artigo 54 em análise, poderá o CADE autorizar a formalização de atos de concentração de empresas, como no caso das joint ventures internacionais, mesmo sobrevindo limitação ou qualquer forma de prejuízo à concorrência, desde que eficiente ou necessárias por motivos preponderantes da economia nacional ${ }^{99}$.

Bastante ilustrativa, como soe acontecer, a explicação formulada por Eros Roberto $\mathrm{Grau}^{100}$ que, afirmando não se justificar a condenação indistinta de todas as práticas restritivas da concorrência quando aos prejuízos delas decorrentes, suportados pelo mercado, ou pela própria concorrência, corresponderem a vantagens a serem auferidas pela economia nacional como um todo, de sorte que estas vantagens sejam relativamente maiores do que aqueles prejuízos, exemplifica:

"Imagine-se, por exemplo, um acordo de cooperação entre duas empresas para o desenvolvimento de uma nova tecnologia. Parece óbvio que a união dos dois agentes econômicos, embora importe na eliminaçáo da concorrência recíproca, pode ser socialmente relevante, de modo a beneficiar o desenvolvimento tecnológico. Se assim é, a união não deve ser obstada, ainda que importe em um certo 'prejuízo para a concorrência'."

Na prática, consequentemente, uma vez configurada a hipótese prevista no $\S 1^{\circ} \mathrm{do}$ artigo 20 da lei especial, deverão os controladores da joint venture em formação, ou já criada, atuar de forma cautelosa, uma vez que estarão na mira das autoridades do CADE, e dos próprios concorrentes, em função da situação privilegiada alcançada ou de provável alcance, não se deixando seduzir por essa posição vantajosa.

infração legal...E, ainda, antes do curso judicial teremos aí um aplicador administrativo da lei com tal amplitude discricionária de caracterização do delito, em um procedimento legal criado, (arts. 39 e ss.) de teor sumário." ROCHA, João Luiz Coelho da. Alguns aspectos heréticos da Lei Antitruste (Lei 8.884/94). Revista de Direito Mercantil, Industrial, Econômico e Financeiro, São Paulo, n.97, 1995. p. 109-110.

${ }^{94}$ Para Paula Forgioni: "A primeira questão que se coloca diz respeito ao verbo 'visar', utilizado na hipótese normativa. Estar-se-ia fazendo qualquer referência à intenção do agente econômico, quando da prática do ato? Se entendermos que sim, deveremos levar em conta, também, o art. $173 \S 4^{\circ}$, da Constituição Federal (que emprega o mesmo verbo) e concluir que 0 art. 20 da Lei Antitruste (que se utiliza da expressão 'independentemente de culpa') é inconstitucional. Ao contrário, se entendermos o verbo 'visar' com o significado de 'ter por objeto ou por efeito', eliminamos da hipótese normativa qualquer referência ao elemento volitivo do agente econômico, e o art. 54 dirá respeito aos atos que têm por objeto ou por efeito 'concentração econômica'. FORGIONI, 1998. p. 380.

${ }_{95}$ CRETELLA JÚNIOR, José. Comentários à Lei Antitruste - Lei nº 8.884/94. 2ed. Rio de Janeiro: Forense, 1996. p. 118. 


\section{CADE}

C - Submissão voluntária da joint venture internacional ao controle prévio do

Quanto aos atos que, nos termos do caput do artigo 54 da Lei n.. 8.884/94, deverão ser levados à apreciação do $\mathrm{CADE}$, pode-se dizer que nem todas as joint ventures internacionais em formação serão passíveis dessa submissão, mesmo que configurada a concentraçáo de poder econômico nas mãos da mesma empresa. Como visto anteriormente, somente as joint ventures que visem à concentração econômica e que "possam limitar ou de qualquer forma prejudicar a livre concorrência, ou resultar na dominação de mercados relevantes de bens e serviços", deverão ser comunicadas ao $\mathrm{CADE}^{101}$.

Interessante é a distinção formulada por Fábio Ulhoa Coelho entre: a) atos reputados limitativos ou restritivos à concorrência pelos agentes econômicos, mas tidos por inofensivos pelo $\mathrm{CADE}$; $b$ ) atos considerados inofensivos pelas partes que o praticam ou desejam praticar, mas tidos como limitativos ou restritivos à liberdade de concorrência pela autoridade antitruste; $\mathrm{e}, \mathrm{c}$ ) atos considerados limitativos ou restritivos à concorrência pelos agentes econômicos que o praticam e pelo $\mathrm{CADE}^{102}$.

Quanto aos primeiros, o autor sugere que a autoridade antitruste não teria competência para aprovar ou rejeitar o ato, de forma que seu julgamento seria pelo desconhecimento do pedido, isto é, manifestação administrativa diversa da aprovação. Com relação ao segundo grupo de atos, sustenta que somente o Poder Judiciário poderia resolver o conflito de interesses, por meio do exame, em ação própria, dos prováveis efeitos jurídicos, econômicos e sociais provocados pelo ato, manifestando-se, a partir daí, pela necessidade ou não de submetê-lo ao exame prévio pelo CADE. Acaso vencedora a tese de que o ato deve ser levado ao crivo antecipado da autoridade antitruste, nesse caso reabre-se o prazo do artigo $54, \S 4^{\circ}$, da Lei n.o $8.884 / 94$. Já, na última hipótese, o CADE decidirá pela aprovação ou rejeição ao ato de acordo com a análise da presença ou não das condições previstas nos $\$ \S 1^{\mathrm{O}}$ e $2^{\mathrm{O}}$ do artigo 54 supramencionado, exercendo, dessa forma, a competência discricionária de agente da política econômica do Governo federal.

A Lei Antitruste nacional estipula, em seu artigo 21, as condutas que caracterizam infraçōes contra a ordem econômica, desde que, é claro, configurada pelos menos uma das hipóteses previstas no artigo 20 do mesmo diploma legal, pois, na legislação antitruste

\footnotetext{
${ }^{96} \mathrm{Na}$ opinião de Luis Fernando Schwartz, "esta regra de raciocínio é relativizada no caso das
} análises de atos - especialmente de concentração - com base no art. 54 da Lei 8.884/94. Aqui é 
não há ilícitos per se. Acaso determinada joint venture tenha por objetivo, ou efetivamente adote qualquer das referidas condutas, poderá incorrer em infração à ordem econômica nacional na medida em que seus atos culminam naqueles repugnados pelos artigos 20 e 54 do mesmo texto legal - prejuízo à livre concorrência e dominação de mercado - sendo necessário, portanto, sujeitar-se ao controle prévio pelo CADE.

Em que pese soar um pouco estranho, é o próprio agente econômico que, analisando e estudando o seu próprio ato, seus efeitos potenciais e concretos (formação ou constituição de joint venture internacional), decidirá se o submeterá, ou não, ao controle prévio do $\mathrm{CADE}^{103}$. Também poderá ser requerida - a interferência do CADE - por quem se julgar prejudicado ${ }^{104}$ pelo negócio formalizado e realizado, ou em vias de realização ${ }^{105}$.

Poder-se-ia perquirir do porquê de tal atitude ou alerta, em caso de dúvida do próprio agente econômico quanto à licitude de seu negócio, se existe a possibilidade

possivel "contrabalançar" os efeitos anticompetitivos com aquilo que se convencionou chamar de "eficiências

" (resultados "positivos") para o mercado. Trata-se de relativização e não de suspensāo, posto que o recurso a tais "eficiências" deixa de valer a partir de uma certa intensidade alcançada pelos efeitos anticompetitivos." SCHWARTZ, Luis Fernando. Dogmática jurídica e Lei 8.884/94. Cadernos de Direito Tributário de Finanças Públicas, São Paulo, v.23, 1998. p. 153.

${ }_{97}$ FORGIONI, 1998. p. 275.

${ }^{98}$ FORGIONI, 1998. p. 276.

99 Nessa orientação, PROENÇA, 2001. p. 64.

100 GRAU, Eros Roberto; e FORGIONI, Paula A. Restrição à concorrência, autorização legal e seus limites. Lei n. ${ }^{\circ} 8.884$, de 1994 , e Lei n. ${ }^{9} 6.729$, de 1979. Revista Trimestral de Direito Público, São Paulo, v.21, 1998. p. 112-113.

101 Nesse sentido, jurisprudência do CADE, no A.C. $n^{\circ}$ 08012.008295/98-86, sendo requerentes as empresas Viking Resins Group Holdings B. V., Vianova Resins GmbH, Vianova Resins Ltda. e Hoechst Aktiengesellschaft: "DESPACHO MC/CADE N²/99: Como visto no relatório, trata-se da transferência do negócio de resinas da divisão Vianova do grupo Hoechst para o grupo Deutsche Bank, um novo entrante no mercado de resinas policondensadas, representado pela holding Viking Resins. Dado que o grupo adquirente não possuía qualquer participação no mercado relevante antes da presente operação, concordo com a SEAE, SDE e Procuradoria do CADE no sentido de que esta não altera a estrutura do mesmo, nem é passivel de limitar ou de qualquer forma prejudicar a livre concorrência, ou resultar na dominação do mercado relevante, nos termos do caput do art. 54 da Lei 8.884/94."

102 COELHO, 1995. p. 125-126. 
de a decisão do $\mathrm{CADE}$ ser contrária à formação do ato visado. A resposta para tal questionamento vem enfrentada nos $\S \S 4^{\circ}$ e $5^{\circ}$ do artigo 54 da Lei Antitruste nacional. Com efeito, se os atos de que trata o caput do artigo 54 não forem apresentados para exame, previamente ou no prazo máximo de quinze dias úteis de sua realização ( $\S$ $\left.4^{9}\right)$, sujeitar-se-ão os partícipes da joint venture internacional à multa ${ }^{106}$ pecuniária entre 60.000 (sessenta mil) e 6.000.000 (seis milhōes) de UFIR's, sem prejuízo da abertura do processo administrativo descrito no artigo 32 e seguintes da lei especial. Assim sendo, tencionado o empresário nacional à constituiçáo de uma joint venture internacional, que por sua vez poderá resultar em prejuízo à livre concorrência ou no domínio de mercado relevante, segundo o mercado brasileiro, deverá encaminhar os documentos competentes ${ }^{107}$ ao controle prévio realizado pelo CADE, ou, em último caso, no prazo máximo de 15 dias úteis de sua realização. Tudo isso sob pena de ser onerado com uma multa que, dependendo da decisão do $\mathrm{CADE}^{108}$, poderá ser bastante pesada às aspirações do empresário nacional, mormente tendo-se em

\footnotetext{
${ }_{103}$ Nesses termos, Fábio Ulhoa Coelho, 1995. p. 125.

104 Chama-se "representante" a pessoa, física ou jurídica, de direito público ou privado, que comunica o fato caracterizador da infração a ordem econômica que a prejudicou ou nele tem interesse. A atuação do representante limita-se à comunicação do fato, tanto na averiguação preliminar quanto no processo administrativo, não se constituindo em parte ou interessado nesse processo, porém atuando unicamente como agente provocador do "poder de polícia" da Administração Pública que não integra a relação jurídica Administração-representado, após a representação. Nesse sentido, LAZZARINI, Alexandre Alves. O papel do representante, do Procurador e do Ministério Público nos procedimentos da Lei 8.884/94. Revista do Instituto dos Advogados de São Paulo, São Paulo, n.2, 1998. p. 223.

105 Exemplo de representação de empresa que se julgou prejudicada por suposto abuso de poder econômico realizado por concorrente sua, foi veiculado pelo Jornal Zero-Hora, edição de 19.05.2001, p. 15. A matéria, de título "Ministério da Justiça pede puniçāo para a Microsoft", retrata a representação feita pela empresa brasileira "Paiva Piovesan" contra a "Microsoft", onde aquela acusa esta de estar infringindo a lei antitruste e o mercado brasileiro de softwares financeiros para Windows, por dominar $96 \%$ do mercado nacional para este tipo de programa, eliminando, assim, a concorrência brasileira. ${ }^{106}$ A cobrança judicial da multa, acaso necessária, será efetuada conforme a Lei de Execuçōes Fiscais, em conformidade com o disposto no artigo 61 da Lei Concorrencial que preleciona: "A execuçăo que tenha por objeto exclusivamente a cobrança de multa pecuniária será feita de acordo com o disposto na Lei 6.830 , de 22 de setembro de 1980." Já, a cobrança administrativa da multa será efetuada de acordo com a Resolução n. ${ }^{9}$, de 16 de julho de 1997, que estabelece o "Regulamento para cobrança das penalidades pecuniárias previstas na Lei $n .{ }^{\circ} 8.884 / 94$ e respectiva inscrição em dívida ativa do Conselho Administrativo de Defesa Econômica (CADE)."

107 São, basicamente, os documentos que deverão ser levados à apreciação prévia do CADE para verificação da validade, ou não, do ato objetivado: "- estatuto ou contrato social das requerentes, de suas subsidiárias e controladoras, com as modificaçōes atualizadas; - relação dos acionistas com direito a voto (pessoas físicas e jurídicas), das requerentes e de suas controladoras, com as respectivas participações, devendo ser agregados os dados referentes aos cônjuges e aos filhos menores, quando sócios ou acionistas, e inclusive de estrangeiros, indicando, nesse caso, o representante no Brasil com poderes expressos para receber citaçōes, intimações ou notificações; - relação de todas as pessoas jurídicas onde os acionistas referidos no item anterior detenham ações com direito a voto ou o poder de indicar diretores, gerentes ou administradores, ou que aufiram $50 \%$ ou mais dos lucros da empresa; cópia das atas das assembléias gerais realizadas nos últimos três exercícios, mesmo daquelas que ainda não foram levadas a registro, e de todos os atos, sob qualquer forma manifestados nos últimos
} 
conta os gastos já anteriormente efetuados no decorrer da negociação com o empresário estrangeiro, com quem deseja constituir uma joint venture.

E quanto às empresas estrangeiras, qual a repercussão do ato infrator ? A Lei n.o 8.884/94 aplica-se, também, a toda empresa estrangeira que opere no Brasil ou que em território nacional pratique ato ou contrato, no todo ou em parte, que possa causar os efeitos previstos no texto legal, bem como em casos de possuir, no país, agência, sucursal, escritório, estabelecimento, agente ou representante ${ }^{109}$. Eis, aí, portanto, a aplicabilidade da legislação antitruste brasileira aos partícipes estrangeiros da joint venture internacional em formação e em operação sob condição resolutiva, que ver-se-á posteriormente.

Sabe-se que, em regra, a fase de negociação ${ }^{110}$ para formação de uma joint venture internacional é bastante demorada, requer grande paciência, e demanda muitos gastos com advogados, troca de material, telefonemas, estudos de viabilidade do negócio, pesquisa de mercado, etc. Destarte, em se tratando de acordo empresarial que projete a constituição de joint venture internacional a ser operacionalizada em território brasileiro, nada mais coerente do que, durante as tratativas da transação, o empresário nacional alerte seu parceiro estrangeiro, antes de se fechar definitivamente o negócio, sobre a necessidade de submeter o ato à apreciação e aprovação do $\mathrm{CADE}$, bem como as possíveis conseqüências desta verificação. Caso não o faça, ad argumentandum tantum, em sobrevindo decisão desfavorável por parte do $\mathrm{CADE}$, ou multa pecuniária devido ao não atendimento dos $\S \S 4^{\circ}$ e $5^{\mathrm{o}}$ supracitados, o agente econômico brasileiro poderá ser até mesmo demandado judicialmente pelos danos decorrentes da má-fé, quebra do princípio da troca de informações e negligência negocial, justamente em função dos gastos realizados pelo parceiro, bem assim por tudo aquilo que este deixou de ganhar com a não realização do negócio.

O princípio da boa-fé, no Direito Internacional Privado, está pautado no dever de mútua informação de tudo aquilo que se apresenta relevante aos negócios visados, de forma que no âmbito das joint ventures assim deverão agir os seus partícipes, informando um ao outro os objetivos visados e os procedimentos adotados em suas respectivas legislaçóes, sob pena de abalar-se o empreendimento conjunto ${ }^{111}$.

Persistindo a mais pequena dúvida, portanto, o melhor que se tem a fazer na condição de agente econômico que deseja ver sua joint venture internacional em operação regular, é lançar-se ao controle prévio do $\mathrm{CADE}$, evitando-se, assim, possíveis infortúnios que poderão, até mesmo, levar à ruína o negócio visado. A submissão de

cinco anos, entre empresas e acionistas, realizados no Brasil ou no exterior, ainda que não registrados, informando o valor da transação, os investimentos efetuados e as eficiências obtidas, sendo que, se não realizado o ato, as requerentes deverão apresentar a minuta daquele que se pretende concretizar; - cópia de todo e qualquer acordo de acionistas, quotistas e/ou quaisquer acordos que incluam regras relacionadas com a administração; - em caso de fusão ou incorporação, cópia do protocolo, das atas das assembléias que deliberaram sobre a fusão ou incorporação e do laudo de avaliação do patrimônio líquido da sociedade especialmente elaborado para a transação; - quaisquer atos e contratos complementares ou adicionais firmados entre as partes; - cópia do último relatório anual elaborado 
um contrato de joint venture ao exame do CADE não significa, necessariamente, a náo-aprovação do mesmo, o que ocorrerá unicamente se verificada qualquer das infrações apontadas no artigo $54 \mathrm{em}$ comento sem que sejam atendidas as chamadas “eficiências” do $§ 1$ do artigo 54 da lei de proteção à concorrência.

\section{D - Notificação obrigatória da joint venture internacional}

Consoante o $\S 3^{0112}$ do artigo 54, incluem-se entre os atos de que trata o caput, e que,por conseguinte impóe-se obrigatoriamente sejam comunicados e submetidos à apreciação do $\mathrm{CADE}$, "aqueles que visem qualquer forma de concentração econômica, seja através de fusão ou incorporação de empresas, constituição de sociedade para exercer o controle de empresas ou qualquer forma de agrupamento societário, que implique participação de empresa ou grupo de empresas resultante em $20 \%$ (vinte por cento) de um mercado relevante, ou que qualquer dos participantes tenha registrado faturamento bruto anual no último balanço equivalente a 400.000 .000 (quatrocentos milhões) de reais, ou unidade de valor superveniente."

É importante lembrar que a notificação não necessita ser procedida anteriormente à constituição da joint venture internacional e, consequentemente, as partes não estão proibidas de consumar a transação visada antes ou durante o exercício do controle prévio realizado pela autoridade antitruste ${ }^{113}$.

Em relação ao elemento quantitativo suprarreferido, comunga-se, no presente trabalho, da opinião exarada pelo ínclito Conselheiro, e atual presidente do CADE, João Bosco Leopoldino Fonseca ${ }^{114}$, segundo a qual "o percentual de $20 \%$ (vinte por cento) é rigoroso e o valor do faturamento tomado como parâmetro é aleatório." Para o autor, "tais parâmetros deveriam ser deixados a critério do $\mathrm{CADE}$, na apreciação do caso concreto, à luz dos princípios legais gerais e específicos que regem a matéria."

$\mathrm{Na}$ doutrina internacional, três argumentos críticos são levantados em respeito a comentada necessidade de comunicação das joint ventures internacionais que alcançam os parâmetros estabelecidos no $\S 3^{\mathrm{O}}$ do artigo $54^{115}$. Primeiramente, o elemento quantitativo, $\mathrm{R} \$ 400$ milhões, não está limitado as receitas obtidas em território brasileiro. Conselheiros do $\mathrm{CADE}$ têm confirmado que o referido parâmetro se aplica a receitas mundiais das empresas $\mathrm{e}$, portanto, joint ventures internacionais com pequeno impacto no mercado brasileiro teriam de ser obrigatoriamente notificadas a autoridade competente. Segundo, os $\mathrm{R} \$ 400$ milhōes, estabelecidos como parâmetro de obrigatoriedade de notificação, podem ser atingidos por qualquer das partes envolvidas na transação, sendo que não existe limite quantitativo para a outra parte.

para os acionistas ou quotistas das demonstraçōes financeiras dos três últimos exercícios sociais, aprovadas pela assembléia geral, acompanhadas das notas explicativas, referentes a todas as requerentes: balanço patrimonial, demonstração de lucros e prejuizos acumulados, demonstração do resultado do exercício, demonstração das origens e aplicações dos recursos e, se se tratar de sociedade anônima de capital aberto, relatório da administração; - relação de todos os administradores das requerentes, suas controladoras e subsidiárias, com indicação dos respectivos cargos, informando-se, ainda, aqueles 
Consequentemente, mesmo uma joint venture internacional de pequena proporções, na qual uma das partes contratantes é uma grande empresa, teria de ser comunicada e submetida à análise do $\mathrm{CADE}$. Terceiro, o teste percentual de $20 \%$ do mercado relevante estabelecido no parágrafo in focu introduz um elemento subjetivo na obrigação de notificar, qual seja a definição de mercado. $O$ grande problema surge quando as partes contratantes e os conselheiros do CADE discordam, de boa-fé, sobre a definição de mercado relevante numa determinada situação, gerando incertezas quanto a necessidade de comunicação do ato ou contrato.

Ainda na esteira dos dois primeiros argumentos supra, poder-se-ia dizer que uma grande quantidade de joint ventures internacionais inofensivas a estrutura do mercado brasileira, economia e consumidores terão de ser assim mesmo notificadas, resultando em custos desnecessários e atraso na regularização da parceria visada. Para evitar custos injustificados e o atraso, bem assim o acumulo de trabalho para o CADE, a seguinte solução tem sido apontada por especialistas na matéria: limitar o parâmetro quantitativo de $\mathrm{R} \$ 400$ milhōes a receitas obtidas no Brasil e adicionar um parâmetro quantitativo de receita mínima a ser obtido pela outra ou outras partes envolvidas na transação ${ }^{116}$. Em ambos os casos, entretanto, haveria a necessidade de questionar-se até que ponto o parâmetro de $\mathbf{R} \$ 400$ milhões não é exagerado, o que parece ser o caso.

No caso das joint ventures internacionais, percebe-se que o limite equivalente a R\$ 400 milhões de faturamento bruto anual registrado por uma das co-venturers tornase ainda mais sem fundamento. Isso porque, se o co-venturer estrangeiro for norteamericano, por exemplo, ou de qualquer outro país que tenha como referencial monetário o dólar (currency board), o valor supracitado é bastante pequeno, tendo em conta o câmbio completamente desfavorável, e que vem batendo recordes desde princípios de 1999, oscilando ultimamente entre $\mathbf{R} \$ 3,00$ e $\mathbf{R} \$ 3,15$, o dólar (câmbio comercial). Assim, nos dias de hoje, o faturamento bruto dessa empresa estrangeira, que queira se associar com uma empresa nacional via joint venture, não poderia ultrapassar a barreira de U $\$ 129.032 .258,06^{117}$, faturamento bastante comum, a não ser que comprovadas as eficiências contidas no $\S 1^{\circ}$ do artigo 54 da Lei n.o 8.884/94.

Com efeito, os parâmetros quantitativos deveriam ser legados à apreciação do $\mathrm{CADE}$ de acordo com o caso concreto, tendo em vista os princípios que regem a matéria, assim como o fora feito no $\S 2^{\circ}$ do artigo 54 da Lei n. $98.884 / 94$, com base no qual se flexibiliza à autoridade antitruste o encargo de escolher quais dentre as condiçóes

eventualmente ocupados pelos referidos administradores em outras empresas, órgãos públicos, empresas públicas ou sociedades de economia mista." PROENÇA, 2001. p. 137-138. No caso de formação de joint venture internacional seria necessário submeter-se à apreciação do CADE, além dos documentos acima 
ali previstas devam prevalecer na análise do ato ou contrato submetido ao crivo prévio, bem assim a determinação de se configurado, ou não, o motivo preponderante relativamente à economia nacional e ao bem comum ${ }^{118}$.

Quanto ao percentual apontado no dispositivo em tela, tem-se que é por demais rigoroso tendo em vista as diferenças existentes entre os diversos mercados relevantes que integram a economia brasileira e mundial. Não se pode olvidar que pode ocorrer de um determinado bem ou serviço não exista no mercado, pelo menos em abundância, de forma que qualquer associação empresarial, por menor que fosse, ocuparia mais do que $20 \%$ (vinte por cento) do mercado.

Os números apontados neste parágrafo indicam, unicamente, a necessidade de submissão da joint venture em formação à apreciação do CADE, sendo que uma vez comprovada a reunião dos requisitos previstos nos $\S \S 1^{\circ}$ e $2^{\circ}$ do artigo 54 , deverá ser autorizada ${ }^{119,120}$.

E - A aprovação das joint ventures internacionais que prejudicam a concorrência ou resultam em domínio de mercado relevante

Se é verdade que uma vez praticados pelas joint ventures internacionais os atos que, nos termos do caput do artigo 54 da lei especial, podem ou efetivamente venham a se caracterizar como infraçōes à ordem econômica, o CADE tem a competência para desautorizá-los, não é menos verdade que se deles (atos) advierem os resultados previstos

descritos: a cópia do acordo-base elaborado pelos co-venturers, contendo os acordos satélites que o complementarāo.

${ }^{108}$ A reterida multa não poderá ser imposta se não verificada qualquer infração tipificada no caput do artigo 54 da Lei n. ${ }^{8} 8.884 / 94$, tampouco permiti-se que seja prévia, visto que caberá tão-somente após decisão definitiva proferida pelo CADE.

109 Nesse sentido: CRETELLA JÚNIOR, 1996. p. 14.

110 Sobre a fase de negociação dos contratos internacionais vale a leitura da obra de Maristela Basso, "O direito internacional do comércio", onde a autora analisa com profundidade a problemática da etapa negocial do contrato.

111 GAMBARO, 2000. p. 68.

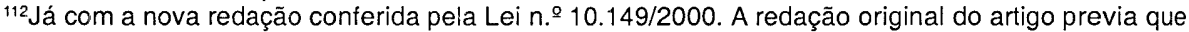
deveria ser submetido à apreciação do CADE quaiquer forma de agrupamento societário que resultasse $30 \%$ (trinta por cento) de um mercado relevante, ou da qual fizesse parte empresa com faturamento bruto anual, no último balanço, equivalente a 100.000.000 (cem milhões) de UFIR's. ${ }_{113}$ Resolução n. 15 do CADE, que regula o exercício do controle prévio, estabelece que a contagem do prazo de 15 dias começa correr no dia em que o primeiro acordo entre as partes seja celebrado, ou no dia em que ocorrer alterações nas relações de concorrência entre os interessados ou pelo menos entre um dos interessados e uma terceira parte.

114 FONSECA, 1995. p. 150.

${ }_{115}$ CLARK, 2000. p. 213-214.

116 Ibidem.

117 Levando-se em conta a cotação do dólar comercial de RS 3,10 - cotação do dia 25.08.2002. ${ }^{118}$ Cf., FONSECA, 1995. p. 149-150.

119 Nesse exato sentido, traz-se à baila jurisprudência do CADE, no Ato de Concentração n. ${ }^{9}$ 08012.008895/98-53, em que são interessadas as empresas Columbian Chemicals Company e Copebrás S.A. O voto é de relatoria de João Bosco Leopoldino Fonseca, no qual conclui que, embora existentes os entraves do $\S 3^{\circ}$ do artigo 54 , não se trata de caso em que resta prejudicada a concorrência: "O presente Ato de Concentração trata da aquisição pela COLUMBIAN da COPEBRÁS NEGRO DE FUMO S.A. constituída pela empresa COPEBRÁS relativamente à produção e 
nos quatro incisos do $\S 1^{\circ}$ do mesmo dispositivo legal, a autoridade antitruste (CADE) não poderá classificá-lo como ilegal, remodelando-o, ou mesmo determinar sua desconstituição ${ }^{121}$.

Se, na formação da joint venture internacional os agentes econômicos tiverem dentre os seus objetivos o aumento da produtividade, a melhoria da qualidade dos bens ou serviços por ela produzidos ou prestados, a eficiência e desenvolvimento tecnológico e econômico, bem como a distribuição eqüitativa desses benefícios entre os participantes do ato e os consumidores, e, por fim, a não-eliminação da concorrência de parte substancial do mercado relevante dos bens e serviços objeto do ato, com observância estrita dos limites necessários a se atingir os objetivos visados, não terá o CADE outra opção senão aprovar-lhe.

Os incisos I a IV do $\S 1^{\circ}$ do artigo 54 estabelecem as diretrizes que deverão conduzir o $\mathrm{CADE}$ no exame prévio dos atos jurídicos. Frise-se que as condiçóes impostas pelo inciso I necessitam ser analisadas pelo órgão fiscalizador de forma potencial, em conformidade com os objetivos da empresa consulente. A linguagem do dispositivo supramencionado poderia ser interpretada como colocando para as partes envolvidas na joint venture o ônus de demonstrar que a parceria é economicamente benéfica. $\mathrm{Na}$ prática, entretanto, o CADE não tem imposto tal ônus, intervindo somente quando conclui que, fazendo-se um balanço dos aspectos positivos e negativos da transaçáo, haveria um significante prejuízo à concorrência.

Não há dúvidas de que através da constituição de uma joint venture internacional o empresário brasileiro busque o aumento da produtividade, a melhoria da qualidade dos bens e serviços a serem por meio dela produzidos ou prestados, bem assim a eficiência e o desenvolvimento tecnológico ou econômico do país, beneficiando a si mesmo, a seu parceiro empresarial, e aos consumidores finais (inciso I). Resta saber até que ponto a sua criação - da joint venture - poderá ser nociva ao mercado e à livre concorrência.

Os critérios da cumulatividade ou alternatividade estão intimamente ligados aos objetivos acima referidos, de forma a se perceber que nunca serão exigidos os três enumerados nas alíneas "a", "b" e "c" do inciso I do $§ 1^{\mathrm{O}}$ do artigo $54^{122}$.

comercialização de negro de fumo, via contrato de compra. O Ato de Concentração em questão foi submetido à apreciação deste Colegiado tendo em vista o faturamento mundial da Columbian de $R \$ 503.004 .000 .000,00$ (quinhentos e três bilhões e quatro milhões de reais) ser superior a $R \$$ $400.000 .000,00$ (quatrocentos milhōes de reais) e a participação de mais de $20 \%$ no mercado relevante enquadrando-se, portanto, no $\S 3^{\circ}$, do art. 54, da Lei 8884/94.Por todo o acima exposto, resta demonstrado que a realização da aquisição do negócio de negro de fumo da COPEBRÁS pela COLUMBIAN não afetará o mercado relevante. Assim, concluo que, não estando presentes os 
Importante, também, que a joint venture internacional em criação preserve, tanto quanto possível, o princípio do equilíbrio contratual, objetivando promover o benefício de todos os seus co-venturers e do consumidor final (inciso II).

Ademais, indiscutível é a necessidade de preservação do princípio da livre concorrência, bastando o domínio parcial do mercado relevante para que a autorização não seja procedida, porquanto inviável a "eliminação da concorrência de parte substancial de mercado relevante de bens e serviços" (inciso III).

Outrossim, a joint venture em formação não poderá significar ameaça ou abuso de poder econômico, como condição essencial para sua aprovação pelo $\mathrm{CADE}$, visto que deverão ser "observados os limites estritamente necessários para atingir seus objetivos" (inciso IV). Esse último dispositivo carece muito de interpretação subjetiva, já que não trabalha com fatos e números concretos de produção, melhoramento $\mathrm{e}$ desenvolvimento.

Cumpre salientar que para fins da Lei n.o 8.884/94, verifica-se o exercício abusivo de posição dominante ${ }^{123}$ quando uma empresa ou grupo de empresas controlar $20 \%$ (vinte por cento) ${ }^{124}$ do mercado relevante, na condição de fornecedor, intermediário, adquirente ou financiador de um produto, serviço ou tecnologia a ele relativa, conforme preconizado nos $\S \S 2^{\circ}$ e $3^{\circ}$ de seu artigo 20 .

Na opinião do insigne jurista Modesto Carvalhosa "a dominação é fenômeno de conduta infringente da lei e se caracteriza quando determinado agente, detentor de posição dominante, manobra e maquina sobre o mercado em que atua para impor ou exercer influência nos preços ou na qualidade, quantidade e condições de fornecimento ou estocagem, de maneira a impor aos demais agentes, restriçōes concorrenciais. ${ }^{125 "}$

obstáculos previstos no artigo 54 da Lei no 8884/94, ou até mesmo, como demonstrado, configurando-se as condiçōes legitimadoras do ato, voto pela aprovação da operação sem restrições, reiterando o ponto de vista de que a apresentação foi intempestiva, deixando-se de aplicar a multa pelos fundamentos já expostos."

${ }_{120}$ Decisão no mesmo sentido foi tomada no Ato de Concentração $n^{0}$ 08012.000297/99-07, em que eram requerentes as empresas TCW/Camil Holding L. L. C. e Cooperativa Agrícola Mista Itaquiense Ltda.: "ATO DE CONCENTRAÇĀO. aquisição pela TCW Holding L. L. C., de 50\% do capital social da empresa Camil Alimentos S/A, pertencentes à Cooperativa Agrícola Mista Itaquiense Ltda. Lei 8.884/ 94 art. 54, $\S 3^{\circ}$. Apresentação tempestiva. Faturamento do grupo TCW superior a R\$ 400 milhões. 
Lembre-se, a posição dominante de per se não é proibida pela lei, mas exclusivamente o abuso de seu exercício. Assim, a título de ilustração, colaciona-se o exemplo apontado na obra do autor supracitado, in verbis: "o agente que produza um volume de $40 \%$ de determinados bens num mercado relevante, tendo como concorrente outros 18 agentes que repartem entre si o restante do mercado não caracteriza em si mesmo, para efeitos de dominação prevista na lei em estudo, 'dominar mercado'. ${ }^{126 " \text { " }}$ Para ele, nessa liderança mercadológica, o agente somente incorreria em ilícito tipificado na lei especial se dominasse os preços e os produtos, abusando de sua posição.

Muito embora reste patente a presença maciça de conceitos subjetivos e indeterminados no comentado artigo 54 da Lei n. $.9884 / 94$, o fato é que são as condiçōes nele previstas que informam a decisão sobre a autorização ou não para a constituição da joint venture, com base na qual os empresários de países distintos visam a realização de empreendimento ou projeto

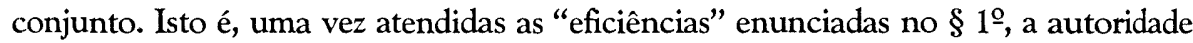
antitruste brasileira ${ }^{127}$ deverá autorizar a prática de atos restritivos da concorrência ${ }^{128}$.

Sempre que o CADE aprovar ato que de qualquer forma seja prejudicial ou restritivo à concorrência, porquanto verificadas, no caso concreto, as "eficiências" do $\S 1$ o do artigo 54 da lei especial, deverá definir os termos do compromisso de desempenho a ser firmado pelos contratantes do ato, em conformidade com o artigo 58.

Mercado nacional de arroz e feijão. Empresa adquirente não atuava no mercado nacional de arroz e feijão. Inexistência de efeitos de concentraçāo horizontal ou integração vertical. Operação aprovada sem restrições."

${ }_{121}$ Nesse sentido MAGALHÃES, José Carlos, SAMPAIO, Onofre Carlos de Arruda. A concentração de empresas e a competência do CADE. Revista de Informaçōes Legislativa, Brasília, n.. 140, 1998. p.112.

${ }^{122}$ Altredo Lupatelli Júnior e Eliane Maria Octaviano Martins entendem que o critério adotado é o da razoabilidade, a exemplo da Comunidade Européia (LUPATELLI JÚNIOR, MARTINS, 1999. p. 182). Esta opinião é confrontada por Eros Roberto Grau e Paula Forgioni que, acertadamente, afirmam que a regra da razão não é aplicável ao sistema brasileiro para fins de descaracterizar a infração à ordem tributária, determinando-se a submissão de qualquer ato que reflita restrição à concorrência à apreciação do CADE para que nāo acarrete a aplicação das sanções previstas em lei. GRAU, FORGIÓNI, 1998. p. 121.

${ }^{125}$ Sobre o abuso de posição dominante de mercado, recomenda-se o artigo, de mesmo título, escrito pelo notável Modesto Carvalhosa, que, com a clareza e brilhantismo que lhe são peculiares, exaure a matéria. CARVALHOSA, Modesto. O abuso de posição dominante de mercado na Lei n.․ 8.884 , de 11 de junho de 1994. Revista Jurídica de Osasco, Osasco, v.3, p. 45-52, 1996.

${ }^{124}$ Percentual reduzido de $30 \%$ (trinta por cento) para 20\% (vinte por cento) pela Medida Provisória n. ${ }^{2} 542$, de 30 de junho de 1994.

${ }^{125}$ CARVALHOSA, 1996. p. 51.

${ }^{126}$ CARVALHOSA, 1996. p. 50

${ }^{127}$ Conforme jurisprudência do CADE, mais uma vez em voto da lavra de João Bosco Leopoldino Fonseca, mesmo havendo concentração de mais de $20 \%$ de mercado relevante, a joint venture deve ser aprovada quando preencher as eficiências constantes do $\S 1^{\circ}$ do artigo 54 da Lei Antitruste. Esta foi a decisão no Ato de Concentração nº 08012.008109/98-08, em que eram requerentes as empresas Chevron Chemical Company LLC, Chevron do Brasil Ltda. e Exxon Corporation: "A Exxon Corporation e a Shell apresentaram a nível mundial a proposta de constituiçāo de joint-venture. Houve preocupação das autoridades antitruste dos EUA e da Europa justamente no que se refere ao mercado de aditivos VII. Conforme relatório da FTC, "o efeito desta joint-venture, se consumado, levaria à diminuição de competição e tenderia a criar um monopólio no mercado relevante violando, 
Ao suportar as práticas anticoncorrenciais, desde que preenchidas as condiçōes dos $\S 1^{\circ}$ do artigo 54 , a Lei Antitruste brasileira afasta, implicitamente, a per se condemnation theory ${ }^{129}$ da legislação americana, familiarizando-se mais com o sistema europeu que adota a "teoria do abuso"130.

Com relação ao $\S 2^{\circ}$ anteriormente mencionado, reflete a aprovação excepcional de determinados atos, pelo CADE no exercício de seu crivo prévio, sem que a satisfação de uma das condições estabelecidas nos incisos I, II, III e IV do artigo 54 seja comprovada. No entanto, cumulativamente, o CADE, na apreciação do ato de concentração, deve levar em conta os "motivos preponderantes da economia nacional e do bem comum" que o inspirou e que podem estar suportados por critérios de conveniência e de oportunidade, desde que, é claro, não prejudique o consumidor ou usuário final.

Verificadas, então, pelo menos três das quatro condiçōes estabelecidas, a autarquia não poderá considerar o ato irregular, devendo autorizá-lo se necessário à economia nacional e ao bem comum. Se necessário ao bem-comum seguramente não atentará aos interesses dos consumidores e usuários finais, o que seria um contrasenso. Outrossim, como já se disse no decorrer deste trabalho, muito dificilmente a realização de atos de concentração não venha a prejudicar, de qualquer forma, o interesse dos consumidores, o que torna ainda mais árdua a tarefa do CADE em decidir, conforme as peculiaridades de cada caso, pela aprovação ou não do ato ou contrato.

F-As caminho adotado pelo CADE na tomada de decisōes e a definição de mercado relevante

Ao tomar suas decisões, o CADE aplica a tradicional forma de análise de atos de concentração econômica também adotado nos Estados Unidos e União Européia, com diferenças condizentes com as peculiaridades de cada sistema, obviamente. Em 1999, a SEAE publicou um guia dos aspectos a ser considerados pela autoridade antitruste na tomada de decisōes, semelhante as "Horizontal Merger Guidelines" americanas. Os cinco passos ("guidelines") descritos a seguir são comumente levados em consideração pelo CADE ao analisar uma joint venture internacional, sem prejuízo de outros que poderão surgir dependendo do caso concreto:

- definição do mercado relevante geográfico;

- determinação de concentração e parcelas de mercado;

- $\quad$ exame das condiçóes para o exercício de poder de mercado;

- consideração dos benefícios econômicos da transação ("eficiências");

- avaliação dos efeitos da transaçáo sob o ponto de vista social.

portanto, a Seção 7 do Clayton Act e a Seção 5 do FTC Act, da seguinte forma: 1) eliminando atual, direta e substancial competiçāo entre a Exxon Chemical Company, Shell Petroleum Company Limited 
A metodologia utilizada para a determinação do produto relevante e mercado geográfico no guia descrito acima é baseado na substituição, pelos consumidores, em resposta a uma mudança hipotética no preço dos produtos. Num segundo passo, o guia descreve parâmetros e medidas para determinar níveis de concentração que considera a possibilidade de exercício de poder de mercado: (a) por uma empresa unilateralmente, quando essa empresa tem pelo menos $20 \%$ de parcela do mercado; ou (b) através de coordenação de empresas, quando a proporção de concentração de quatro empresas é de pelo menos $75 \%$. Se a concentração de mercado exceder um dos dois parâmetros o terceiro passo será acionado, no qual consideraçóes sobre condições de mercado relacionadas com a possibilidade de exercício de poder de mercado será feita. As condições incluem a oportunidade de crescimento de importação, condições de entrada no mercado, e fatores que facilitem a coordenação entre rivais. Se questóes concorrenciais persistirem, a análise procede com a consideração das chamadas "eficiências" que a transação possa gerar (quarto passo) e, finalmente, com a avaliação dos efeitos econômicos do negócio visado ${ }^{131}$.

Como visto, o primeiro e decisivo passo na tomada de decisões pelo CADE é a definição do mercado relevante. O termo é de elástica definição, pois, conforme sustenta a grande maioria dos autores "derivará de uma somatória que isole, inicialmente, o bem a ser analisado, comparando-o em termos territoriais, produção e venda, tendo em vista o $\S 1$ o do próprio artigo 20 desta lei, sob pena de uma desmotivação à empresa séria e plena de trabalhadores capacitados. ${ }^{132}$ "

Sem sua definição resta impossível a verificação da incidência de qualquer das hipóteses previstas nos incisos do artigo 20 ou no caput do artigo 54, porquanto só é possível verificar-se à restrição de concorrência, domínio de mercado ou abuso de posição dominante, concretamente, se referidas a um determinado mercado.

Por "mercado relevante" entende-se, dentre outras definiçōes, aquele no qual se travam as relações de concorrência ou atua o agente econômico cujo comportamento está sendo analisado ${ }^{133}$. Benjamin Shieber, ao comentar o diploma legal (Lei n.o 4.137/ 62) que antecedera a atual Lei Antitruste, sugere definição de mercado relevante, extraída do contexto jurisprudencial, como sendo: "composto de produtos que razoavelmente

e Shell Oil Company no mercado relevante, 2) aumentando a possibilidade ou facilitando a colusão entre a joint-venture e competidores remanescentes, 3) aumentando a possibilidade de que consumidores do aditivo VII tenham que pagar altos preços, 4) reduzindo inovação, qualidade, serviço e avaliação do produto no mercado relevante e 5) entrada de um novo competidor não ocorreria em tempo hábil, provável ou suficiente de tal forma que compense a perda de competiçāo ocasionada pela jointventure". O Ato de Concentração em questão foi submetido à apreciação deste Colegiado em virtude do percentual de participação da Requerente, por ser superior aos $20 \%$ previstos na Lei $8.884 / 94$. Em virtude do exposto e considerando as eficiências decorrentes da operação em questão, decido pela sua aprovação, sem restrições. É o voto."

${ }_{128}$ Cf. GRAU, FORGIONI, 1988.p. 115.

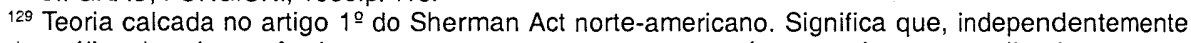
da análise das circunstâncias que cercam o caso concreto, será automaticamente aplicada a sanção prevista em lei ao contrato ou ajuste que restringe o comércio ou a indústria entre os Estados daquele país. Como forma de amenizar a inflexibilidade de sua legislação antitruste, a Suprema Corte americana tem recorrido a regra da razão (rule of reason), segundo a qual o artigo 1 은 
podem ser substituídos um pelo outro quando empregados nos fins para os quais são produzidos - levando em consideração o preço, a finalidade e a qualidade deles ${ }^{134}$."

A doutrina é quase uníssona ${ }^{135} \mathrm{em}$ afirmar que a determinação de mercado relevante requer conjugação de dois elementos complementares e inseparáveis: o mercado relevante geográfico e o mercado relevante material (ou do produto) ${ }^{136}$.

O mercado relevante geográfico seria a área onde se verifica a concorrência relacionada à atividade a que se atribui características restritivas, devendo ser considerados, para a sua delimitação, os seguintes aspectos: a) hábitos dos consumidores; $b$ ) incidência de custos de transporte; c) características do produto; d) incentivos de autoridades locais; e, e) existência de barreiras à entrada de novos agentes econômicos no mercado ${ }^{137}$.

De outra banda, o mercado relevante material seria aquele no qual, tendo como base o bem ou serviço que fornece, o agente econômico enfrenta a concorrência. Paula A. Forgioni ${ }^{138}$, em obra já inúmeras vezes citada, argumenta com a tendência mundial verificada por parte das autoridades antitruste em limitar cada vez mais a extensão dos mercados relevantes materiais, para fins de "caracterizar, com maior profundidade, a posição dominante do agente econômico; potencializar os efeitos anticompetitivos de uma determinada prática; e impedir que as práticas sejam tomadas como minor agreements (ou acordos de pouca relevância), isentos de obrigação de comunicação ou de pedidos de isençóes ou autorizaçōes às autoridades antitruste (como poderia ocorrer, p. ex., no caso do $\S 3 . \mathrm{o}$ do art. 54 da Lei 8.884/94)." ${ }^{139}$ Com base no ora exposto, percebe que a fixação de conceitos e definiçóes de marcados relevantes, nos quais atuam as joint ventures, configura-se estratégia utilizada pelo CADE, em sua atuação, para adequar suas decisões à concretização da política econômica.

\section{G-Revisão e efeitos jurídicos das decisões tomadas pelo CADE}

Admitindo-se que a decisão proferida pelo Plenário do CADE seja feita no prazo legal, obviamente duas poderão ser as hipóteses em relação à pretensão dos empresários que objetivam a formação da joint venture internacional: a de seu deferimento e a de seu indeferimento.

Os efeitos da decisão indeferitória, ou seja, aquela que nega aprovação ao ato submetido ao crivo prévio do $\mathrm{CADE}$, são tratados no $\S 9^{\circ}$ do artigo 54 , que dispóe: "Se os atos especificados neste artigo não forem realizados sob condição suspensiva ou deles já tiverem decorrido efeitos perante terceiros, inclusive de natureza fiscal, o Plenário do $\mathrm{CADE}$, se concluir pela sua não-aprovação, determinará as providências cabíveis no sentido de que sejam desconstituídos, total ou parcialmente, seja através de distrato, cisão de sociedade, venda de ativos, cessão parcial de atividades ou qualquer outro ato ou providência que elimine os efeitos nocivos à ordem econômica, independentemente da responsabilidade civil por perdas e danos eventualmente causados a terceiros." 
Assim sendo, uma vez não aprovada a joint venture levada à apreciação do CADE, a decisão por este proferida retroagirá ao início da prática dos atos por aquela realizados, obviamente, em condição resolutiva ( $\$ 7^{\circ}$ do artigo 54$)$, estabelecendo-se, mediante qualquer das formas apontadas no dispositivo, o status quo ante. Os atos realizados pela joint venture sob condição resolutiva, em caso de decisão desfavorável do $\mathrm{CADE}$, não são considerados práticas infracionais, a ponto de não serem impostas punições ao requerente. Isso não quer dizer, entretanto, que não estejam os agentes econômicos que regularmente praticaram os atos enquanto o feito tramitava no $\mathrm{CADE}$, sujeitos à indenizar os terceiros prejudicados, responsabilidade esta que deverá ser verificada em Juízo.

A desconstituição do ato poderá ser total ou parcial, dependendo do caso concreto e dos prejuízos causados à livre concorrência, aos consumidores, ou à economia nacional, sempre tendo-se como norte o objetivo precípuo de evitar, sanar ou interromper os danos econômicos sentidos pela sociedade em geral.

Acaso sobrevindo o indeferimento do ato levado à apreciação preliminar do CADE, a decisão somente poderá ser revista na esfera judicial ${ }^{140}$, haja vista que o artigo 50 da Lei n. $9.884 / 94$ estabelece que as decisões desta autarquia federal não comportam revisão na esfera administrativa. As decisões deferitórias do contrato de joint venture, no entanto, poderão ser revistas de ofício ou a requerimento da Secretaria de Direito Econômico do Ministério da Justiça, se baseadas em informaçōes falsas ou enganosas prestadas pelo interessado, ou em caso de ocorrer descumprimento de obrigaçōes assumidas por ocasião da aprovação, ou ainda quando não forem alcançados os benefícios visados - artigo 55 da Lei n.o 8.884/ 94.

Saliente-se que se o CADE rejeitar a aprovação de determinado ato, por considerá-lo prejudicial ou restritivo à concorrência, ou mesmo por entender que dele resultará dominação de mercado relevante, deverá examinar o cabimento de instauração de processo administrativo para investigação de infrações contra a ordem econômica, porventura praticadas, ainda que o ato tenha sido celebrado sob condição suspensiva, tendo em vista os objetivos visados - artigo 20 da lei de proteção à concorrência.

à concorrência. Foi essa a decisão tomada no leading case Standard Oil Co. of New Jersey $v$. United States of America. Cf. GRAU, FORGIONI, 1988. p. 103.

${ }^{130}$ Nesse sentido, FONSECA, 1995. p. 143-146.

${ }_{131}$ A aplicação do procedimento indicado pelo guia formulado pela SEAE tomou maior repercussão nas decisões dos casos Colgate-Kolynos e Mahle-Metal Leve pelo CADE.

132 POPP, ABDALA, 1994. p. 73.

133 FORGIONI, 1998. p. 200.

134 Conceito de dominação dos mercados nacionais na Lei Antitruste. Apud FONSECA, 1995. p. 91. 
Da análise do controle prévio realizado pelo CADE quando da formação das joint ventures internacionais, nos termos do artigo 54 da Lei Antitruste nacional, tem-se que a decisão indeferitória do acordo empresarial não está calcada na efetiva existência de abuso do poder econômico, senão que implicitamente significa dizer que a experiência demonstra que determinada soma de poder centralizado nas mãos de apenas uma empresa redundará em abuso do poder econômico, materializado na manipulação do mercado de acordo com suas necessidades e/ou ambições que, por sua vez, podem ser nefastas a toda ordem econômica e a seus competidores.

\section{IV - A defesa dos consumidores e a Lei n. $\stackrel{0}{8.884 / 94}$}

Muito embora a defesa dos consumidores seja objeto de tutela em lei específica e própria - o Código de Defesa dos Consumidores - também configura-se em princípio constitucional consagrado no inciso IV do artigo 170 da Constituição Federal, no mesmo nível do princípio da livre concorrência (inciso $\mathrm{V}$ do mesmo dispositivo constitucional), sendo ambos limitadores da liberdade de iniciativa e da autonomia da vontade ${ }^{141}$.

Na livre concorrência está garantido o estabelecimento de regras para que o consumidor não seja explorado por produtos inadequados, impossíveis de ser aceitos em economia de livre mercado, regras estas que concorrem para que as empresas desenvolvam ou ofereçam o melhor produto ou serviço pelo menor preço, com a qualidade e garantia que a propaganda anunciar ${ }^{142}$.

Nessa linha de raciocínio, é verdadeiro afirmar que "a concorrência é entendida como a disputa de agentes econômicos para a satisfação da escolha de um cliente ou adquirente de produtos. ${ }^{143}$ "

Na Lei n. $.8 .884 / 94$, vem a defesa do consumidor calcada no artigo 20, inciso III, que coíbe o aumento arbitrário de lucros por parte do agente econômico, bem assim no inciso II do artigo 54 , que determina sejam distribuídos eqüitativamente os benefícios previstos no inciso I, entre os produtores e os consumidores. Vê-se, outrossim, abrigado o princípio da defesa dos consumidores pela parte final do $\S 2$ - do artigo 54 da

\footnotetext{
${ }_{135}$ Nesse sentido: COELHO, Fábio Ulhoa, 1995. p. 58; PROENÇA, José Marcelo Martins, 2001. p. 116; FORGIONI, 1998. p. 201; SANTOS, Antônio Carlos, GONÇALVES, Maria Eduarda, e MARQUES, Maria Manuel Leitão. Direito Econômico. Coimbra: Almedina, 1991. p. 393; FRANCESCHINI, José Inácio Ganzaga. Introdução ao direito da concorrência. São Paulo: Malheiros, 1996. p. 32.

${ }^{136}$ Da mesma forma entende o CADE, conforme denota-se da decisão proferida no processo administrativo 31/92: "O mercado relevante é o espaço da concorrência. Diz respeito aos diversos produtos ou serviços que concorrem entre si, em determinada área, em razão de sua substitutibilidade naquela área. Sua definição se faz necessária, in casu, tanto em termos geográficos quanto em relação ao serviço."

137 Nesse sentido, FORGIONI, 1998. p. 205-207.

${ }^{138}$ Para maior aprofundamento sobre a matéria, recomenda-se a leitura da obra de Paula Forgioni, que inclusive cita diversas delimitações de mercados relevantes materiais, ilustrando melhor o tema.

FORGIONI, 1998. p. 207-216.
}

139 FORGIONI, 1998. p. 215. 
lei em comento, que trata da aprovação excepcional, condicionando-a a inexistência de prejuízos aos consumidores e usuários finais.

À primeira vista, é de se estranhar a repressão ao aumento arbitrário dos lucros por considera-lo infração à ordem econômica, já que vai de encontro aos interesses do mercado que, do contrário, deste beneficia-se pelo aumento do grau de competitividade em determinado mercado relevante. $\mathrm{O}$ alcance de altos lucros é indicador de concorrência potencial, portanto lícita e saudável, que atrai os agentes econômicos estimulados pela possibilidade de recompensa, tornando, por conseguinte, a concorrência potencial efetiva. Assim sendo, outra interpretação não há para o referido dispositivo legal senão aquela que diz com o objetivo precípuo de proteção ao consumidor ${ }^{144}$.

O aumento arbitrário dos lucros, para ser configurado, prescinde de eventual abuso de posição dominante exercido pelo mesmo agente econômico, já que tratadas, essas formas de infração à ordem econômica, separadamente no artigo 20 da lei em comento.

Para Paula A. Forgioni ${ }^{145}$, quando os especialistas em "direito antitruste" fazem referência à proteção dos consumidores, fazem-no tendo em vista os adquirentes dos produtos ou serviços, independentemente de que sejam consumidores finais ou não.

Tal interpretação tem gerado muita polêmica entre aqueles que se dedicam especificamente ao estudo do "direito do consumidor" ${ }^{146}$. Isso porque, segundo os especialistas nas relaçóes de consumo, a amplitude do conceito jurídico de consumidor pode transformar-se em óbice até mesmo para o desenvolvimento desta nova área do Direito, pois, em assim sendo, o conceito em questão pode confundir-se com seu similar econômico, não havendo por que se tutelar de forma especial aos consumidores, já que todos, inclusive as empresas produtoras, o seriam ${ }^{147}$.

\footnotetext{
${ }^{140}$ A possibilidade de revisão judicial das decisões tomadas pelo CADE é matéria de trabalho específico que não guarda compatibilidade com o objeto do presente trabalho, qual seja a formação das joint ventures internacionais conforme a Lei Antitruste brasileira. Para aprofundamento acerca do tema sugere-se a leitura do capítulo referente a possibilidade de revisão judicial dos atos administrativos, nas obras de Hely Lopes Meirelles (Estudos e pareceres de direito público, 1992); Sérgio Varella Brunna (O poder econômico e a conceituação do abuso em seu exercício, 1997); José Júlio Borges da Fonseca (Direito antitruste e regime das concentrações empresariais, 1997); Walter Douglas Stuber e Lionel Pimentel Nobre (Atuaçāo do CADE no Brasil); Tércio Sampaio Ferraz Júnior (Discricionariedade nas decisōes do CADE sobre atos de concentraçāo).

${ }^{141}$ Esclarecedores são os ensinamentos de Cláudia Lima Marques sobre a limitação à autonomia da vontade em face do Código de Defesa do Consumidor. Vale a transcrição de parte de sua obra,

in verbis: "No Brasil, essa intervenção estatal nas relações de consumo deu-se especialmente através da imposiçāo pelo novo CDC, de normas imperativas. Estas normas cogentes (art. 1., CODECON), em matéria contratual, limitam o espaço antes reservado para a autonomia da vontade, impondo deveres aos elaboradores dos contratos, criando novos direitos para os consumidores e tutelando determinadas expectativas dos contraentes, oriundas da sua confiança no vínculo contratual. MARQUES, Cláudia Lima. Novas regras sobre a proteçāo do consumidor nas relaçōes contratuais. Revista do Direito do Consumidor. São Paulo: Revista dos Tribunais, v. 1, 1992. p. 32.
} 
Em realidade, o conceito jurídico de consumidor é dado pela Lei n.o 8.078 / 90 que, em seu artigo $2^{\circ}$ refere: "Consumidor é toda pessoa física ou jurídica que adquire ou utiliza produto ou serviço como destinatário final." 148

O conceito ${ }^{149}$ adotado pelo Código de Defesa do Consumidor, com razão, tem caráter finalista, fático-econômico.

Uma das maiores autoridades na matéria, senão a maior, define a questão com maestria, colocando-lhe um ponto final. Na abalizada opinião da Doutora Cláudia Lima Marques, a interpretação conferida ao conceito jurídico de consumidor jamais poderá ser maximilista, mas essencialmente finalista, reconhecendo-se o destinatário final mediante uma análise fático-econômica do caso concreto. Cumpre transcrever o trecho de sua obra, de contribuição imensurável, no qual ensina com propriedade:

"Segundo esta interpretação teleológica não basta ser destinatário fático do produto, retirá-lo da cadeia de produção, levá-lo para o escritório ou residência, é necessário ser destinatário final econômico do bèm, não adquiri-lo para revenda, não adquiri-lo para uso profissional, pois o bem seria novamente um instrumento de produção de novos benefícios econômicos (lucros), o bem estaria sendo transformado novamente, usado como instrumento de produção cujo preço será incluído no preço final do profissional que o adquiriu. ${ }^{150}$ "

O consumo é uma das atividades mais praticadas e difundidas no mundo todo, incidindo em grande parte dos atos praticados pelas pessoas, razão pela qual torna-se impossível de imaginar o âmbito de aplicação do "direito do consumidor". Em assim sendo, a defesa e proteção jurídica do consumidor mostra-se tema de tamanha magnitude que atinge a quase todos os setores do ordenamento jurídico ${ }^{151}$, justificandose sua tutela em lei especial.

142 MARTINS, Ives Gandra da Silva. Direito Constitucional Econômico. Cadernos de Direito Tributário e Finanças Públicas, São Paulo, v. 18, 1997.p. 232.

${ }_{143}$ SILVEIRA, Paulo Antônio Caliendo V. da. Defesa da Concorrência no Mercosul. São Paulo: Ltr, 1998. p. 47.

${ }^{144}$ Nesse sentido, FORGIONI, 1998. p. 235.

145 FORGIONI, 1998. p. 236.

${ }^{146}$ Cláudia Lima Marques, especialista que é no assunto, adota a teoria finalista no conceito de consumidor, também utilizada na Alemanha. Para a insigne autora, a definição finalista, ou restritiva, traz em seu bojo as características de consumidor mais aceitas no âmbito internacional, quais seja,: "a de sua não-profissionalidade, de pessoa física (a relembrar o uso familiar, coletivo ou pessoal dos produtos e serviços adquiridos ou usados), de contratante ou partícipe de um negócio jurídico visando produtos e serviços." MARQUES, Cláudia Lima. Normas de proteção ao consumidor (especialmente, no comércio eletrônico) oriundas da União Européia e o exemplo de sua sistematizaçāo no Código Civil alemão de 1896. Revista de Direito Privado. Sāo Paulo: Revista dos Tribunais, v.4, 2000. p. 78. ${ }^{147}$ Antônio Herman V. Benjamin (O conceito jurídico de consumidor) e Toshio Mukai (Comentários ao Código de Proteção do Consumidor), apud POPP, ABDALA, 1994. p. 31.

${ }^{148}$ Parágrafo Único: "Equipara-se a consumidor a coletividade de pessoas, ainda que indetermináveis, que haja intervindo nas relações de consumo."

${ }^{149}$ Sobre o tema, Eros Roberto Grau discorre: "há de ser esboçado a partir da verificação de que, adotando, os mercados, formas assimétricas, consumidor é, em regra, aquele que se encontra em uma posição de debilidade e subordinação estrutural em relação ao produtor do bem ou serviço de 
A magnitude do direito do consumidor é revelado, também, pelo fato de que mesmo os contratos regulados por leis especiais são subordinados às normas gerais do Código de Defesa do Consumidor, em face do caráter de ordem pública interna constitucional que estas assumem, nos termos do artigo $1^{\mathbf{o}}$ da Lei $\mathrm{n} . \mathbf{o}$ $8.078 / 90^{152}$. Sua aplicação incontinenti se dá pela superioridade que possuem as regras de defesa do consumidor sobre outras leis, não importando os critérios de anterioridade e especialização ${ }^{153}$.

É justamente por isso que a defesa dos consumidores serve, juntamente com os outros princípios que regem a ordem econômica, como parâmetro de aplicação da Lei Antitruste, conforme se depreende do seu artigo 1 .

Trata-se, a defesa dos consumidores, de princípio constitucional impositivo que cumpre duas funções: a de instrumento de realização do fim de assegurar a todos existência digna, e de objetivo particular a ser alcançado, sendo que neste último sentido "assume feição de diretriz - norma-objetivo - dotada de caráter constitucional conformador, justificando a reivindicação pela realização de políticas públicas ${ }^{154}$."

Da análise do Código de Defesa do Consumidor chega-se à conclusão de que sua natureza de lei protetora de um grupo social específico está calcada em três fundamentos principais: a sua origem constitucional, sua definição como norma de ordem pública e sua caracterização como norma de interesse social ${ }^{155}$. Em se tratando de normas de ordem pública ${ }^{156}$, são indisponíveis à vontade das parte.

Dois são os princípios contidos no Código de Defesa do Consumidor ${ }^{157}$ que asseguram os direitos aos consumidores: o princípio da boa-fé e o princípio da confiança ${ }^{158}$. São eles "os paradigmas de conduta que efetivam o respeito aos direitos do consumidor ${ }^{159}$."

A intervenção estatal, fiscalizadora e repressora, na economia é necessária sempre que configurado o monopólio natural de atividade econômica de produção de bens ou serviços, para fins de evitar que a função reguladora de preços e fornecimentos seja exercida exclusivamente por e em proveito daqueles que detêm o poder econômico,

consumo. Essa concepção tem a virtude, ademais, de bem adaptar as situações de consumo e de fruição, esta como aquela na qual se coloca o 'usuário' (contemplativo) do patrimônio históricoartístico-natural." GRAU, Eros Roberto. A ordem econômica na Constituição de 1998. 6.ed. São Paulo: Malheiros, 2001. p. 274.

${ }^{150}$ MARQUES, Cláudia Lima. Contratos no Código de Defesa do Consumidor. São Paulo: Revista dos Tribunais, 1992. p. 67.

${ }^{151}$ Nesse sentido: DONATO, Maria Antonieta Zanardo. Proteção ao consumidor - conceito e extensão. São Paulo: Revista dos Tribunais, 1994. p. 33.

${ }^{152}$ Cf. MARQUES, 1992. p. 97. A renomada autora exemplifica: "O espírito protetor do CDC exige que suas normas sobre cláusulas abusivas, por exemplo, sejam aplicadas para anular cláusula presente em contrato de transporte aéreo, que exclui o direito de indenização do consumidor por vícios ou fato do serviço, mesmo que tal cláusula fosse permitida pela Lei específica, Lei 7.656, de 19 de dezembro de 1986. O caso é basilar, pois a autonomia de vontade antes assegurada e protegida em lei, foi afastada por norma de ordem pública, posterior e com fins sociais." 
resguardando, na medida do possível, os consumidores e a sociedade em geral de eventuais prejuízos que venham a sofrer em decorrência da prática desleal.

Nos Estados Unidos, país cuja legislação antitruste tem por finalidade precípua a livre concorrência dentro da ordem econômica, não se encontram dispositivos semelhantes ao inciso III do artigo 20 da Lei n.o 8.884/94 e $§ 1^{\mathrm{o}}$ do artigo 86 do Tratado da União Européia (Maastricht). Pelo sistema norte-americano, não há qualquer interesse jurídico na repressão ao lucro abusivo.

Isso não quer dizer, porém, que a legislação norte-americana não almeje, de qualquer forma, a proteção dos interesses dos consumidores, principalmente tendo em vista sua aplicação à uma população extremamente consumidora. Em realidade o faz, contudo de maneira indireta, mediante a proteção da livre concorrên cia ${ }^{160}$.

A autoridade antitruste, deve, portanto, atentar para a distinção entre os objetivos das leis brasileira e norte-americana, mormente para evitar a transposição de princípios, institutos e jurisprudência que, pertencendo a realidades e culturas quase que antagônicas, não são compatíveis entre si, devendo ser-lhes atribuídas interpretaçóes que se coadunam com os valores (interpretação axiológica) e finalidades (interpretação teleológica) que orientam os respectivos ordenamentos jurídicos ${ }^{161}$.

Obviamente não se pode comparar um e outro sistema à míngua das diferenças sócio-econômico-culturais existentes entre Brasil e Europa, de um lado, e os Estados Unidos de outro. No entanto, não há como se negar as virtudes da legislação norteamericana que, tendo como objetivo principal a defesa da livre concorrência, estimula a vantagem competitiva dos agentes econômicos, gerando benefícios para os consumidores em geral e para a economia mais forte do mundo. E mais, nesse sistema, aqueles que abusarem dos preços, sobremaneira, serão tirados da concorrência naturalmente pela população que, esclarecida, não mais procurará seus produtos e serviços. A questão é de educação e informação sobre os direitos inerentes aos consumidores; e é nesse sentido que o Brasil tem de trabalhar.

\section{V-Conclusão}

A hodierna e crescente internacionalização da economia, ocasionada principalmente pela redução das barreiras ao comércio exterior, pela rapidez do avanço tecnológico e pelo amplo acesso à comunicação, torna quase que inviável a atuação

${ }_{153}$ Cf. Cláudia Lima Marques. O Código Brasileiro de Defesa do Consumidor e o Mercosul. Estudos sobre a proteção do consumidor no Brasil e no Mercosul. Porto Alegre: Livraria do Advogado, 1994. p. 103. Para a autora, "o caráter de ordem pública da norma em estudo é também importante porque a destaca hierarquicamente. Também no Brasil, as antinomias entre as normas do sistema (por exemplo, normas civis e normas comerciais, normas especiais para determinadas atividades econômicas e normas gerais, leis especiais para determinados contratos, como leasing, locação, alienação fiduciária, contratos bancários etc, e regras gerais sobre contratos) resolvem-se com base nos três critérios clássicos: anterioridade, especialidade e hierarquia. Sendo que, em caso de conflito entre critérios (lei geral posterior e lei especial anterior, por exemplo), a hierarquia pode ser o critério definidor usado pelo juiz." p. 103.

${ }^{154} \mathrm{Cf}$., GRAU, 2001. p. 272 - citando Canotitho e Dworkin.

155 Nesses termos: MARQUES, 1994. p. 100.

${ }^{156} \mathrm{O}$ artigo $1^{\circ}$ do Código de Defesa do Consumidor defini suas próprias normas como sendo de ordem pública. Reza o supracitado artigo: "Art. 1.ㅇ O presente Código estabelece normas de proteção 
empresarial, num mercado extremamente concorrido, para aqueles que não acompanharem o desenvolvimento industrial mundial.

Nesse contexto surgem as joint ventures, "expressão utilizada na linguagem comercial para aludir a qualquer acordo empresarial, para realização de projeto específico, independentemente da forma jurídica adotada. ${ }^{162 "}$

Evidentes são as vantagens obtidas pelos agentes econômicos que se utilizam dessa forma associativa para implementação de negócios ou projetos conjuntos, em face, antes de mais nada, de sua enorme flexibilidade. Em realidade, tanto a empresa estrangeira, como a empresa local, bem assim o próprio país hospedeiro gozam dos benefícios que esta modalidade jurídica atual de parceria empresarial proporciona.

Muito embora patente os benefícios supracitados, no momento da formação ou constituição das joint ventures internacionais, principalmente as de grande porte, devem ser observadas as repercussões destas parcerias para a ordem econômica interna, onde atuará, tendo-se como parâmetro a proteção da livre concorrência e defesa do consumidor, princípios consagrados pela Constituição Federal e que regem a própria economia nacional.

Destarte, objetivando-se evitar que abusos do poder econômico sejam praticados pelos agentes econômicos, na forma de dominação de mercado relevante ou eliminação da concorrência, determinadas joint ventures internacionais, antes mesmo de iniciar sua regular operacionalização, devem ser submetidas ao crivo prévio da autoridade antitruste para que esta analise, sob a égide concorrencial da Lei 8.884/94, as implicaçóes do ato objetivado para a ordem econômica nacional.

Buscou-se, via de conseqüência, no presente trabalho, abordar a atuação do $\mathrm{CADE}$ e dos próprios agentes econômicos, quando da formação das joint ventures internacionais, $\mathrm{e}$ criticar, mais especificamente, as disposições e condiçōes estabelecidas no artigo 54 da Lei Antitruste brasileira, que trata do controle dos atos e contratos e a forma na qual se procede, chegando-se às conclusões a seguir articuladas em ordem de exposição:

1. Nem toda a joint venture internacional necessita ser submetida ao crivo prévio do $\mathrm{CADE}$, mas somente aquelas mediante as quais se visa a concentração econômica e vislumbra-se possível o prejuízo à livre concorrência, ou que possa resultar em dominação de mercado relevante. No entanto, prevalecendo a dúvida por parte dos co-venturers, recomenda-se sejam lançadas ao controle prévio da autoridade antitruste, sob pena de incorrerem em pesada multa pecuniária, pelo atraso na apresentação do contrato para exame, sem prejuízo da instauração de processo administrativo para apuração de infração contra a ordem econômica. Até mesmo porque, sob condição resolutiva poderão dar início as suas atividades, submetendo-se, é claro, à responsabilização frente terceiros acaso o ato venha a ser reprovado pelo $\mathrm{CADE}$.

2. Toda a joint venture internacional que resultar na participação de $20 \%$ (vinte por cento) de um mercado relevante, ou que tenha como um de seus partícipes empresa com faturamento bruto anual, no último exercício, equivalente a 400.000.000 (quatrocentos 
milhões) de reais, deverá ser encaminhada, necessariamente, ao exame prévio do CADE, nos termos do $\S 3^{\circ}$ do artigo 54 , supramencionado. Isso não quer dizer, no entanto, que não possam ser aprovadas, conforme demonstrado pela jurisprudência colacionada, da própria autoridade antitruste.

3. São os próprios agentes econômicos, terminada a fase de negociação da joint venture internacional e excetuando-se os casos do $\$ 3^{\circ}$ do artigo 54 , societária ou contratual, que, analisando concretamente os efeitos jurídicos potenciais ou efetivos da transação ou negócio, decidirão, então, pela necessidade, ou não, de submeter-se à aprovação prévia e administrativa do CADE.

4. As joint ventures internacionais que satisfaçam as condiçōes, também chamadas de eficiências, previstas nos $\S 1^{\circ}$ do artigo 54 da Lei n. $9.884 / 94$, ainda que de qualquer forma sejam restritivas à concorrência, deverão ser aprovadas. Assim, se na formação da joint venture internacional os agentes econômicos tiverem dentre os seus objetivos, o aumento da produtividade, a melhoria da qualidade dos bens ou serviços por ela produzidos ou prestados, a eficiência e desenvolvimento tecnológico e econômico, bem como a distribuição eqüitativa desses benefícios entre os participantes do ato e os consumidores, e, por fim, a não-eliminação de parte substancial do mercado relevante dos bens e serviços objeto do ato, com observância estrita dos limites necessários a se atingir os objetivos visados, não terá o $\mathrm{CADE}$ outra opção senão aprovar-lhe.

5. Por ocasião do vencimento do prazo de 60 dias conferido ao CADE para apreciação do ato ou contrato que lhe é submetido ao crivo prévio, será automaticamente aprovada a joint venture internacional. Uma vez aprovado automaticamente o ato por decurso do prazo, torna-se impossível a revisão da aprovação, uma vez que, se possível fosse, tornar-se-ia ineficaz a parte final do preceito contido no $\S 7^{\circ}$ do artigo 54 da Lei n.o 8.884/94.

6. Com relação a questão institucional, é verdadeiro dizer que o envolvimento de três agèncias, independentes, na análise dos efeitos concorrenciais de transações submetidas ao crivo prévio tornam o procedimento um tanto quanto complexo para advogados, negociantes e para as próprias autoridades que podem divergir quanto as decisóes tomadas. Outrossim, o curto mandato dos Conselheiros responsáveis pela coordenação do controle prévio gera insegurança quanto aos profissionalismo, eficiência e independência da autoridade antitruste.

7. Tendo em vista o aspecto conceitual, a legislação concorrencial é viciada por inúmeros dispositivos considerados vagos, sendo que não foi, até o momento, estabelecido e providenciado um guia mais detalhado para de aplicação que facilitasse o desenvolvimento das atividades da agência competente. O principal problema se verifica na falta de parâmetros para definição de mercados relevantes, porquanto não existe fórmula para estabelecer as 
parcelas de mercado e níveis de concentração econômica. Conseqüência disso, incertezas quanto a necessidade de notificação de algumas joint ventures internacionais ao CADE aparecem as partes envolvidas na transação.

8. Tal subjetivismo excessivo verificado no diploma legal em comento é prejudicial aos interesses maiores do desenvolvimento econômico e da justiça social, porquanto inviabiliza uma atuação mais adequada e juridicamente segura da autoridade antitruste na aplicação da lei ao caso concreto. Isso porque a falta de parâmetros predeterminados, pode acarretar erros na aplicação da lei que, se não prejudicam a própria economia nacional quando se deixa de aprovar determinada joint venture internacional benéfica aos interesses brasileiros, podem limitar ou restringir a livre concorrência, como no caso de aprovação de ato que deveria ser reprovado, lesando, via de conseqüência, os consumidores.

9. Em respeito ao aspecto substancial, algumas questōes surgem da análise da dispositivo legal que dispóe sobre a notificação obrigatória (artigo 54 , § 3º, da Lei n. 8.8884/ 94). Os parâmetros quantitativos contidos na referida norma pode forçar que as partes envolvidas em joint venture de pequenas proporções, não restritiva à concorrência, tenham de submeter-se ao controle prévio do $\mathrm{CADE}$, incorrendo, portanto, em despesas desnecessárias e tendo de esperar um grande período de tempo até que possam começar operar o negócio visado com o nível de segurança ideal para transaçóes internacionais. $O$ problema poderia ser resolvido com a imposiçáo de limites no parâmetro de receitas para incluir tão-somente as receitar geradas e obtidas em território brasileiro, assim como através da inclusão de um mínimo de receita a ser alcançado pela outra parte envolvida na parceria. 